\title{
An insight on the role of photosensitizer nanocarriers for Photodynamic Therapy
}

\author{
MARIANA Q. MESQUITA ${ }^{1,2}$, CRISTINA J. DIAS ${ }^{1}$, SARA GAMELAS ${ }^{1}$, MARGARIDA \\ FARDILHA ${ }^{2}$, MARIA G.P.M.S. NEVES ${ }^{1}$ and MARIA AMPARO F. FAUSTINO ${ }^{1}$ \\ ${ }^{1}$ Department of Chemistry and QOPNA, University of Aveiro, Campus Universitário de Santiago, 3810-193 Aveiro, Portugal \\ ${ }^{2}$ Department of Biomedical Sciences and iBiMED, University of Aveiro, Campus \\ Universitário de Santiago, 3810-193 Aveiro, Portugal
}

Manuscript received on October 9, 2017; accepted for publication on November 19, 2017

\begin{abstract}
Photodynamic therapy (PDT) is a modality of cancer treatment in which tumor cells are destroyed by reactive oxygen species (ROS) produced by photosensitizers following its activation with visible or near infrared light. The PDT success is dependent on different factors namely on the efficiency of the photosensitizer deliver and targeting ability. In this review a special attention will be given to the role of some drug delivery systems to improve the efficiency of tetrapyrrolic photosensitizers to this type of treatment.
\end{abstract}

Key words: Photodynamic therapy, Drug delivery, Liposomes, Silica nanoparticles, Gold nanoparticles, Polymeric micelles.

\section{INTRODUCTION}

According to the World Health Organization, cancer is the second leading cause of death worldwide and for instance, it was estimated that 595,690 American citizens died from cancer in 2016, corresponding to about 1,600 deaths per day (Siegel et al. 2016). Nearly 13 million of cancer cases are diagnosed every year, and it is expected that the number of deaths will increase to 13.1 million in 2030 (Lucky et al. 2015).

\footnotetext{
Correspondence to: Maria Amparo F. Faustino

E-mail: faustino@ua.pt

Maria G.P.M.S. Neves

E-mail: gneves@ua.pt

* Contribution to the centenary of the Brazilian Academy of Sciences.
}

The main types of cancer treatments include surgery, chemotherapy, radiotherapy and immunotherapy, either alone or using the combination of two or more of these therapies (Agostinis et al. 2011, Liu and Yang 2016, Miller et al. 2016). However, all these treatments have associated drawbacks. Chemotherapy is frequently related with several side effects, such as nausea, vomiting and diarrhea and it is usually accompanied by hair loss and alopecia (Krukiewicz and Zak 2016, Sun et al. 2005, Tosti et al. 2005). Surgery, on the other hand, requires general anesthesia and several days or weeks of hospitalization, and a high recurrence rate is associated with surgical resection of tumors (Triesscheijn et al. 2006). The side effects of radiation therapy that may have doselimiting potential include diarrhea, mucositis, skin 
toxicity, and xerostomia (Stubbe and Valero 2013). Consequently, further progresses are needed and a good approach consists in concentrating efforts on other known methodologies that are not yet fully appreciated.

Therefore, photodynamic therapy (PDT) has emerged as an important therapeutic approach to treat cancer, infections, and other diseases (Almeida et al. 2011, Alves et al. 2015, Gupta et al. 2013, Hamblin and Mroz 2008, Van Hillegersberg et al. 1994, Spring et al. 2015). This methodology combines the action of light at an appropriate wavelength to activate special drugs called photosensitizers (PS); in addition, the presence of an adequate amount of molecular oxygen in the tissue is also required (Van Hillegersberg et al. 1994). The excited PS generated by light activation then transfers its absorbed energy to molecular oxygen, generating cytotoxic reactive oxygen species (ROS), especially singlet oxygen $\left({ }^{1} \mathrm{O}_{2}\right)$ that oxidizes the target tissue, leading to permanent damage and provoking cell death by necrosis, apoptosis or autophagy (Van Hillegersberg et al. 1994, Makky et al. 2011). However, since ${ }^{1} \mathrm{O}_{2}$ owns a short half-life in water $(\sim 3 \mu \mathrm{s})$, it only causes photodamage in its direct vicinity (Castano et al. 2004, Nosaka and Nosaka 2017). Therefore, the phototoxicity efficiency is highly dependent in the intracellular accumulation of the PS, as well as of its subcellular localization (Castano et al. 2004, Hamblin and Mroz 2008). So, in PDT the required three components on their own do not possess any toxic effect on the biological systems, unlike chemotherapy drugs that induce systemic toxicity, and the ionizing radiations of radiotherapy that damages neighboring normal tissues.

PDT appears as a treatment modality for several types of diseases comprising superficial tumors, such as basal cell carcinomas, head and neck tumors, as well as tumors accessible to endoscopy, such as lung and esophageal cancers (Agostinis et al. 2011, Allison et al. 2005, Dolmans et al. 2003, Kadish et al. 2012, Saini et al. 2016, Toratani et al. 2016). Besides the oncological field, this methodology can also be applied in the inactivation of pathogenic microorganisms (Almeida et al. 2014, Alves et al. 2011, Bonnett et al. 2006, Carvalho et al. 2007, Costa et al. 2010, Mesquita et al. 2014). One of the main benefits of the photodynamic approach on the inactivation of microorganisms is that it is improbable that mechanisms of resistance can be developed, due to the multi-target character of the photodynamic process (Costa et al. 2011, Mesquita et al. 2014, Tavares et al. 2010, 2011, Winckler 2007).

Succinctly, in PDT of tumors, the photoactive PS is firstly administered to the patient, followed by a waiting period for PS body distribution and selective retention by the tumor cells. Then, the tumor is exposed to light of appropriate wavelength to excite the PS molecules and to generate ROS responsible by cell death, damage of tumor microvasculature, or even induction of a local inflammatory reaction ( $\mathrm{Hu}$ et al. 2011, Iranifam 2014).

A high number of PSs that are being considered in clinical or in PDT experimental studies are based on derivatives of protoporphyrin IX, the free-base of heme, the prosthetic group of hemoproteins like hemoglobin. These derivatives present significant photoactivity and the drug biodistribution and pharmacokinetics are dependent on the peripheral substituents and on their composition (Agostinis et al. 2011, Bonnett 1995, Makky et al. 2011). The first formulation approved for PDT of cancer under the trade name of Photofrin (also known as Photosan or Porfimer Sodium) is based on this type of PSs, justifying the special attention given to natural or synthetic porphyrins and analogues (Agostinis et al. 2011, Castano et al. 2004, DeRosa and Crutchley 2002, Erzinger et al. 2011, Kadish et al. 2012, Ormond and Freeman 2013).

Therefore, the main advantages of PDT over other conventional cancer treatments are: 
(i) low systemic toxicity due to the fact that PS is only activated in the presence of light; (ii) ability to destroy tumor cells selectively; (iii) can be applied alone or in combination with other therapeutic modalities, such as chemotherapy, surgery, radiotherapy or immunotherapy; and (iv) it is often cheaper than other cancer treatments (Chilakamarthi and Giribabu 2017, Juarranz et al. 2008). Despite the aforementioned advantages, PDT possesses also some drawbacks: (i) the PS often used in the treatment are water-insoluble molecules, and consequently their injection into the body is not easy; (ii) patients who are treated with the available PS may get sensitive to light for a while, thus light exposure precautions must be taken after the treatment; (iii) lack of PS targetcell specificity; and (iv) limited light penetration in the tissues if the conventional light (600-700 $\mathrm{nm}$ ) is used because it cannot penetrate deeper than $10 \mathrm{~mm}$ into the skin to reach the tumor site, thus limiting PDT to treat only superficial tumors such as skin cancer, nasopharyngeal cancer and oral cancer (Hu et al. 2011, Huang et al. 2013, Iranifam 2014, Laptev et al. 2006, Theodossiou et al. 2003). Nevertheless, PDT has been used to treat other types of cancer such as digestive tumors, prostate cancer and brain tumors (Agostinis et al. 2011).

Ideally, a PS agent should be a single and pure compound that preferentially accumulates in tumor tissue, with insignificant dark toxicity, thereby minimizing phototoxic side-effects and rapidly clearing from the normal tissue (Agostinis etal.2011, Bonnett 1995, Juarranz et al. 2008). Amphiphilicity is another feature that PS must possess because when the PS is systemically administered it requires some degree of hydrophilicity. However, in order to the PS bind to target cells, some degree of lipophilicity is needed. Additionally, they must have good photophysical properties such as high quantum yields of triplet state formation, high singlet oxygen production and also a suitable triplet lifetime to interact with ground state oxygen or other substrates, to generate an appropriate amount of ROS (Agostinis et al. 2011, Allison and Sibata 2010, Juarranz et al. 2008). Most importantly, PSs should have good absorption on the therapeutic window, between 600 and $800 \mathrm{~nm}$ (red to deep red region of the electromagnetic spectrum); photon absorption at wavelengths greater than $800 \mathrm{~nm}$ does not offer enough energy to excite molecular oxygen to its singlet state, one of the main ROS formed upon irradiation. Consequently, since the penetration of light into tissue is enhanced with its wavelength, agents with strong absorbance in the red region, such as chlorins, bacteriochlorins and phthalocyanines (Figure 1) can offer an improvement in tumor control (Agostinis et al. 2011). However, the majority of existing PSs do not satisfy all of these requirements; it is recognized that an important focus must be given to the development of PSs that can be activated with light of longer wavelength, causing shorter generalized photosensitivity and, more importantly, that possess high tumor specificity.

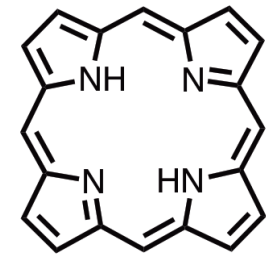

Porphyrin

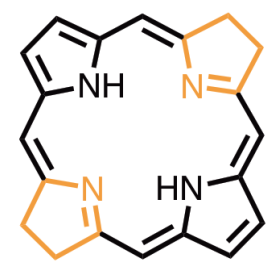

Bacteriochlorin

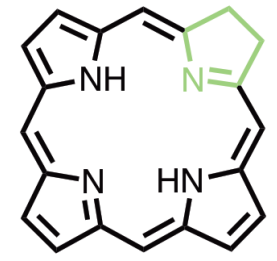

Chlorin
Figure 1 - Structures of some nucleus present in natural and synthetic PSs used in PDT. 
One of the main challenges in PDT as in other therapies is related with the drug delivery (Master et al. 2013, Ogawara and Higaki 2017). For an efficient PDT treatment, it is essential that the PS will be delivered in therapeutic concentrations to the target cells with little or no uptake by non-target cells, thus minimizing undesirable side-effects in healthy tissues (Gupta et al. 2013, Ogawara and Higaki 2017). As the majority of effective PSs are highly hydrophobic, several encapsulation approaches have been considered to minimize the formation of inactive aggregates in an aqueous environment (Krasnovsky et al. 1994, Master et al. 2013, Ogawara and Higaki 2017, Tada and Baptista 2015). It is well known that aggregation reduces the efficiency of the PS, which must be in monomeric form to be photoactive (Konan et al. 2002). Many of delivery systems are based on nanoparticles (NP) or other nanostructures (Chatterjee et al. 2008, Master et al. 2013). NPs, with a size ranging from 1 to $100 \mathrm{~nm}$, reveal unique physical and chemical properties and are being exploited to deliver PSs, in order to improve the current treatment regimens in PDT (Chatterjee et al. 2008, Konan et al. 2002, Master et al. 2013, Ogawara and Higaki 2017).

In this revision it will be discussed the biological effectiveness of some drug delivery systems in PDT of cancer, namely the ones related with liposomes formulations, silica and gold NPs and polymeric micelles. In Figure 1 are represented some structures of the nucleus present in natural and synthetic PSs that will be referred along this review. We would like to mention that no attempt was made to cover all types of formulations and papers concerning this topic, but to show the essential features of the selected nanocarriers and how a PDT treatment can be improved by their use.

\section{THE DRUG DELIVERY SYSTEMS IN PDT OF CANCER}

The use of nanotechnology in PDT is responsible for new advances in this field by providing efficient nanoscale PSs delivery systems, which are able to improve the treatment efficacy and to minimize many side effects associated with classic PDT. NPs were probably first conceptualized by Birrenbach and co-worker (Birrenbach and Speiser 1976). As aforementioned, they are an umbrella term for nanospheres and nanocapsules with diameters less than $100 \mathrm{~nm}$ (Gupta et al. 2013). The potential interest in NPs as drug carriers has been increasing in recent years due to several reasons: (i) they can transport hydrophobic drugs in blood; (ii) their surface area can be modified with functional groups for additional chemical/biochemical properties; (iii) a controlled release of drug is possible; (iv) they have large distribution volumes and are generally taken up efficiently by cells; and finally (v) a high number of different synthetic strategies are available (Calixto et al. 2016, Couvreur et al. 1986, Florence and Hussain 2001, Gupta et al. 2013).

Molecules based on hydrophobic cores like porphyrins and analogues own very poor solubility in aqueous media causing certain limitations for their potential use in PDT (Temizel et al. 2014). Despite accomplishing a better solubility of the PS with the incorporation of some water solubilizing groups, such as $\mathrm{HSO}_{3}^{-}, \mathrm{COO}^{-}$and $\mathrm{NR}_{4}^{+}$on the PS peripheral positions, the delivery of hydrophobic PSs to the tumor cells is still an important PDT goal (Derycke and de Witte 2004, Postigo et al. 2004). Besides the PS water solubility issue, undesired PS interactions with proteins or biomolecules in aqueous medium are also a concern in clinical applications of PDT. On the other hand, the hydrophobicity of the cell membrane can hinder the approach of the ionized PS toward the cells (Temizel et al. 2014). All these obstacles are 
responsible for the special attention given by the scientific community to the PSs cell distribution by different vehicles (Calixto et al. 2016, Chen et al. 2005, Dragicevic-Curic et al. 2009, Namiki et al. 2004). Common approaches used for the formulation of PSs are based on the encapsulation of the photosensitizing agent in colloidal carriers, such as oil-based dispersions (Allémann et al. 1997, Biolo et al. 1996, Chen et al. 2005, Feofanov et al. 2002, Wöhrle et al. 1999), micelle systems (van Nostrum 2004), liposomes (Chen et al. 2005, Derycke and de Witte 2004), biodegradable NPs (Allémann et al. 1995, 1996, Konan et al. 2003, Stevens et al. 2004), and also on the conjugation of the PS with hydrophilic polymers such as polyethylene glycol (PEG) (Brasseur et al. 1999, Fehr et al. 2000, Hamblin et al. 2001) or polylysine (Hamblin et al. 1999, 2003, Silva et al. 2006, 2010, Soukos et al. 1997). As it was already mentioned, in the next sections the main focus will be given to the most commonly types of NPs used to deliver porphyrins and analogues and how these systems affect the efficiency of the photodynamic treatment. Figure 2 summarizes the structures of important PSs studied by different groups to evaluate the importance of the drug delivery in PDT efficacy.

\section{LIPOSOMES}

Liposomes are found to be one of the most efficient vehicles to carry hydrophobic molecules in aqueous medium (Bader et al. 1984, Medina et al. 2004). They are vesicles with one or more concentric phospholipid bilayer(s), making them biocompatible due to their lipid composition (Figure $3 \mathrm{a}$ and $3 \mathrm{~b}$ ). Similar to any bilayer membrane structure, liposomes possess two compartments: an aqueous core (hydrophilic) and a lipophilic space among the lipid bilayer (hydrophobic) as it can be observed in Figure 3a (Banerjee 2001, Chen et al. 2005). Thus, this provides the flexibility to encapsulate both hydrophilic and hydrophobic molecules, which can be seen as an advantage. They can simply encapsulate the hydrophobic molecules, during the bilayer formation, into the lipophilic space due to their hydrophobic ends (Decker et al. 2012). Consequently, loaded liposomes can easily transport the hydrophobic drug in aqueous medium to the target tissue and the similarity between their structures and the cell membrane, allows an easy diffusion and the drug unload into the cytoplasm (Salvati et al. 2007). Additionally, their nanometric size (classically 60-120 nm) confer them a high loading capacity of the therapeutic agent. All these properties make this type of systems effective vehicles for the delivery of drugs in PDT (Banerjee 2001, Chen et al. 2005, Sneider et al. 2017).

Certain improvements in liposomal technology and molecular biology have been done, allowing them to have targeting power in order to achieve selective delivery to specific biological targets (Medina et al. 2004). In fact, the accumulation of liposomes in the tumor tissue is mostly due to the leakage of tumor blood vessels and also to the impairment of the lymphatic systems exhibited by most tumor tissues (Jain 2001). Leaky blood vessels allow more liposomes to diffuse through the vasculature, and the impairment of the lymphatic system leads to a continued retention/ uptake of liposomes in the tumor interstitial area. This enhanced permeability and retention effect (EPR) is the main explanation for the selective tumor accumulation of liposomes (Chen et al. 2005, Maeda 2001). Despite the efficiency shown by these vehicles, any liposomal formulation needs to balance the liposomal stability in the circulation with drug availability/release once it reaches the target tissue (Drummond et al. 1999). Under perfect conditions, the photosensitizing agents are stably preserved in a liposome and are then selectively released in the target tissue. However, it is known that the drugs' physicochemical properties, as well as the tissue environment and liposomal structures can affect the liposomal stability and consequently 

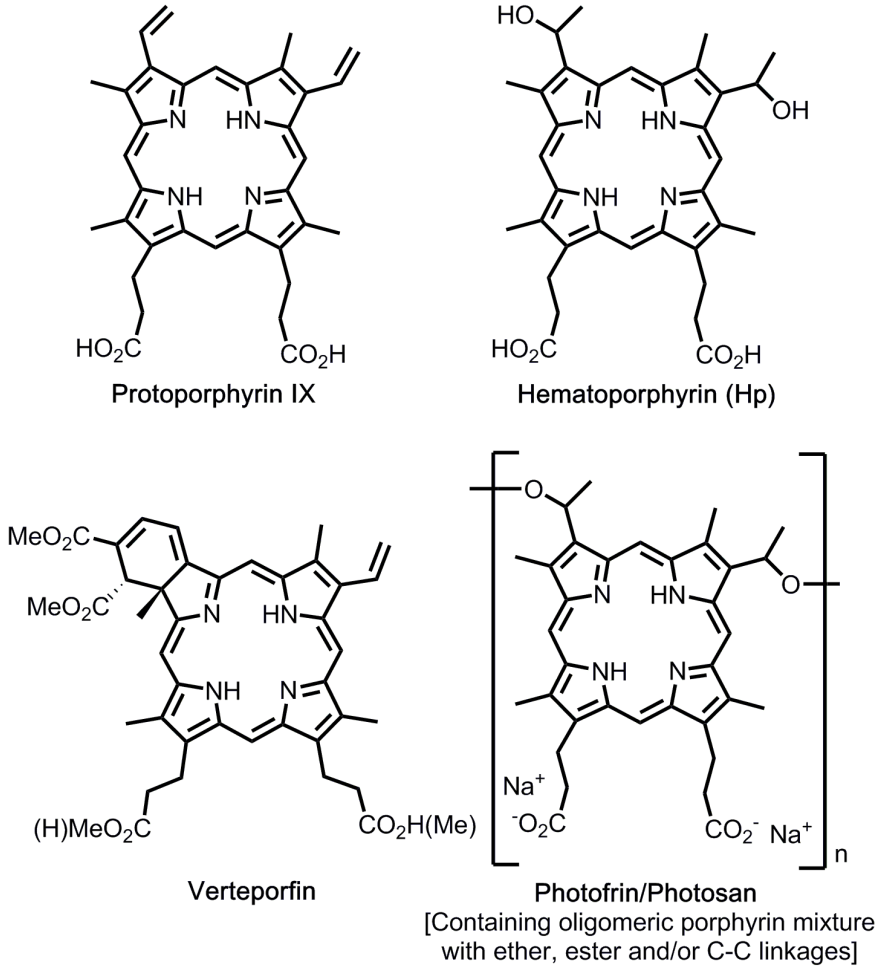
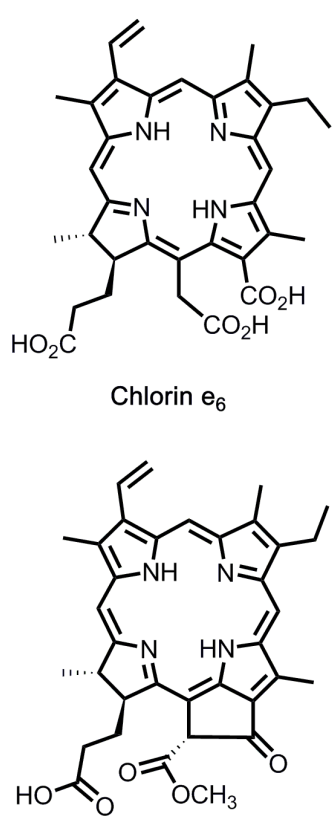

Pheophorbide $a$

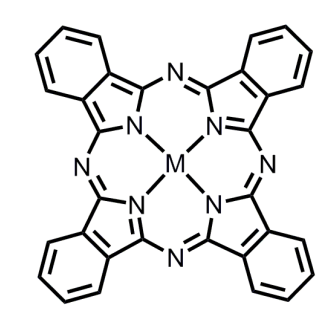

$\mathrm{M}=2 \mathrm{H}, \mathrm{Zn}$ or $\mathrm{AlCl}$

Free phthalocyanine, zinc(II) phthalocyanine or chloroaluminium phthalocyanine

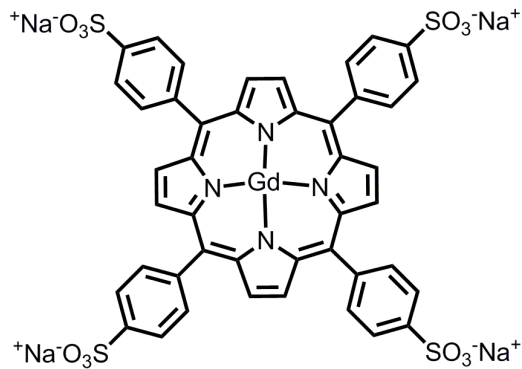
Gadolinium(III) complex of tetrasulfonated porphyrin (TPPS ${ }_{4}$ )

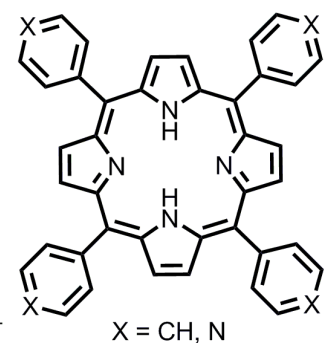

$5,10,15,20$-tetraphenylporphyrin
(TPP, $X=\mathrm{CH}$ )
$5,10,15,20$-tetrapyridylporphyrin (TPyP, $X=N$ )

Figure 2 - Structures of the main PSs discussed in the next sections of this review.

may influence the release of the therapeutic agents from these vehicles (Al-Ahmady et al. 2016, Luo et al. 2016).

Highly hydrophilic drugs can be stably carried within the liposomal aqueous compartment while in circulation, but low membrane diffusion can restrict the release of these drugs into the target tissue. These drugs tend to associate with lipid components of liposomes and to be redistributed to plasma proteins before reaching the target tissue. On the other hand, amphiphilic drugs are being considered the most suitable for liposomal formulation. The structure of the liposome can also affect the liposomal stability and the drug release. The presence of cholesterol and saturated phospholipids increases the rigidity of liposomes but reduces the drug release, while liposomes comprising additional fluid lipid components can easily break up and release the drug during circulation (Drummond et al. 1999). 


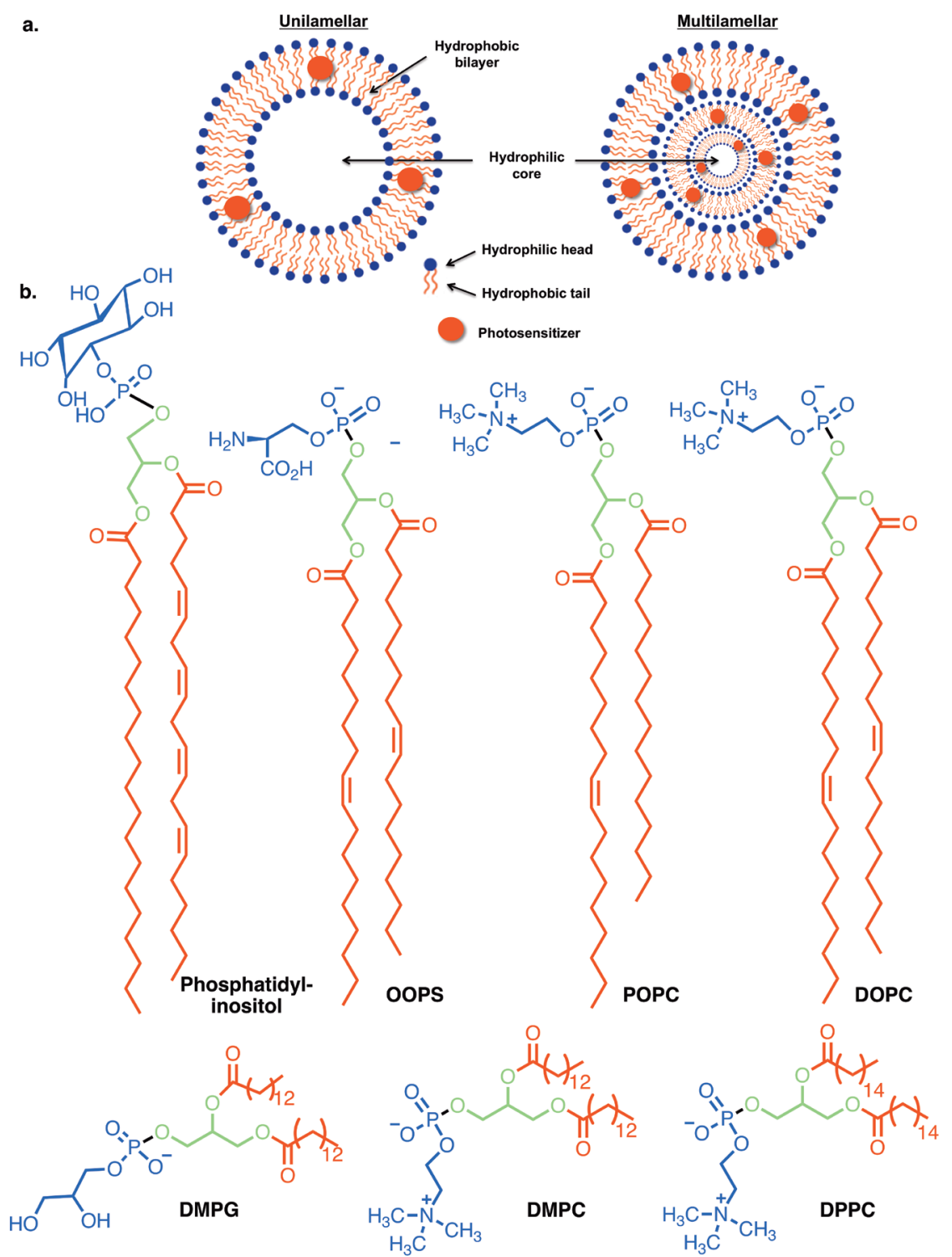

Figure 3 - a. Schematic representation of a unilamellar and multilamellar liposome comprising lipid soluble PS in hydrophobic lipid bilayer; and b. Structures of the most employed phospholipids used to prepare liposomes for drug delivery proposes.

In several studies, liposomes with a high loading capacity and flexibility to encapsulate PSs, such as porphyrin derivatives or analogs (Figure 2), have been used as delivery systems for improving the efficiency of PDT (Cordeiro et al. 2012, Damoiseau et al. 2001, Deng et al. 2013a, Kepczyński 2002, Nam et al. 2017, Polo et al. 1995, Temizel et al. 2014).

Hematoporphyrin (Hp) or its derivative $(\mathrm{HpD})$ and Photofrin (a partially purified form of $\mathrm{HpD}$ ) (Figure 2) were the first PSs to be encapsulated in liposomes based on L- $\alpha$ dipalmitoylphosphatidylcholine (DPPC) (Figure 3b) (Cozzani et al. 1985, Spikes 1983). For instance, the incubation of HeLa cells with equivalent concentrations of either $\mathrm{Hp}$ in aqueous solution, or Hp and its dimethylester encapsulated in unilamellar liposomes showed that the liposomal porphyrins were able to bind to cells at a higher rate and in a significantly larger amount than the 
aqueous solutions of $\mathrm{Hp}$. Also, the release of the porphyrins from the cells into the cell culture medium was remarkably reduced and slower with the liposomal porphyrins. The study showed that the photodamage occurred preferentially in the cytoplasmic membrane and in the membranes of cell organelles and the PDT efficiency was remarkable increased when both PS were incorporated in liposomes (Cozzani et al. 1985). A similar situation was reported when $\mathrm{Hp}$ encapsulated in the same liposomes was injected in tumor-bearing mice; longer tumor retention and significantly higher tumor selectivity were observed (Jori et al. 1983). On the other hand, Li et al. (Jiang et al. 1997, 1998) encapsulated Photofrin (Figure 2) in an unilamellar DPPC liposome and compared the tumor drug uptake and PDT response with Photofrin delivered in a dextrose solution. They found that liposomal Photofrin led to an improvement in the tumor drug uptake and even produced more tumor injury than Photofrin in dextrose, in both 9L rat gliosarcoma (Jiang et al. 1997) and U87 human glioma xenograft in athymic nude rats (Jiang et al. 1998). However, the damage to regular brain tissue was comparable between the two delivery systems. Similar results were obtained in a human gastric cancer xenograft using Photofrin (Figure 2) entrapped in multilamellar liposomes composed of L- $\alpha$-dimiristoylphosphatidylcholine (DMPC) and dimyristoylphosphatidylglycerol (DMPG) and cholesterol (Figure 3b) (Igarashi et al. 2003). The results showed that liposome formulation is responsible for a higher concentration of PS in the tumor when compared with non-liposomal Photofrin, resulting in an improvement of the PDT efficacy.

Knowing that the preservation of the PS monomeric state is an important feature for an effective generation of ${ }^{1} \mathrm{O}_{2}$, liposomal formulations have been also extensively used to improve the PDT efficiency of other natural types of porphyrins (Bachor et al. 1995) or of synthetic porphyrins such as 5,10,15,20-tetraphenylporphyrin (TPP) (Figure 2) (Ježek et al. 2003, Lovčinský et al. 1999) and dimers linked by an amide bond based on mesotetraarylporphyrins (Faustino et al. 1997, 2000), chlorins, bacteriochlorins and phthalocyanines, as it was revised by Chen et al. (Chen et al. 2005).

An interesting publication related with synthetic porphyrins was reported in 2004, by Postigo et al. (Postigo et al. 2004). The authors studied the incorporation of TPP and 5,10,15,20-tetrapyridylporphyrin (TPyP) (Figure 2) and of their $\mathrm{Zn}(\mathrm{II})$ and $\mathrm{Mn}(\mathrm{III})$ complexes in intermediate unilamellar liposomes and multilamellar vesicles using different lipid/ porphyrin ratios. The phospholipids selected were L- $\alpha$-palmitoleoylphosphatidylcholine (POPC), DPPC, DMPC and L- $\alpha$-dioleoylphosphatidylserine (OOPS) (Figure 3b) and it was showed that the incorporation of porphyrins into the carriers could be related to their ability to form aggregates in aqueous media; it was found that the $\mathrm{Zn}$ (II) complex of TPP with less tendency to aggregate, was efficiently incorporated into liposomes. So, it was claimed that hydrophobic porphyrin derivatives structures with less tendency to aggregate than that TPP complex can be efficiently incorporated into liposomes, and consequently can be useful for clinical applications (Postigo et al. 2004).

In another study, carried out by Nawalany et al. (Nawalany et al. 2009), other photosensitizing systems based on the synthetic meso-tetraarylporphyrins: (1) 5,10,15,20-tetrakis(4-hydroxyphenyl)porphyrin ( $p$-THPP) encapsulated in sterically stabilized liposomes $\left.(N \text {-[methoxy(polyethyleneglycol })_{2000}\right]$ carbonyl-1,2-dipalmitoyl-sn-glycero-3phosphoethanolamine sodium salt) and (2) $p$-THPP covalently attached to polyethylene glycol $\left(\mathrm{PEG}_{2000}\right)$ were studied in vitro (Figure 4a). The dark and photocytotoxicity of both systems were evaluated on two cell lines: a human colorectal carcinoma cell line (HCT 116) and a prostate cancer cell line (DU 
a.

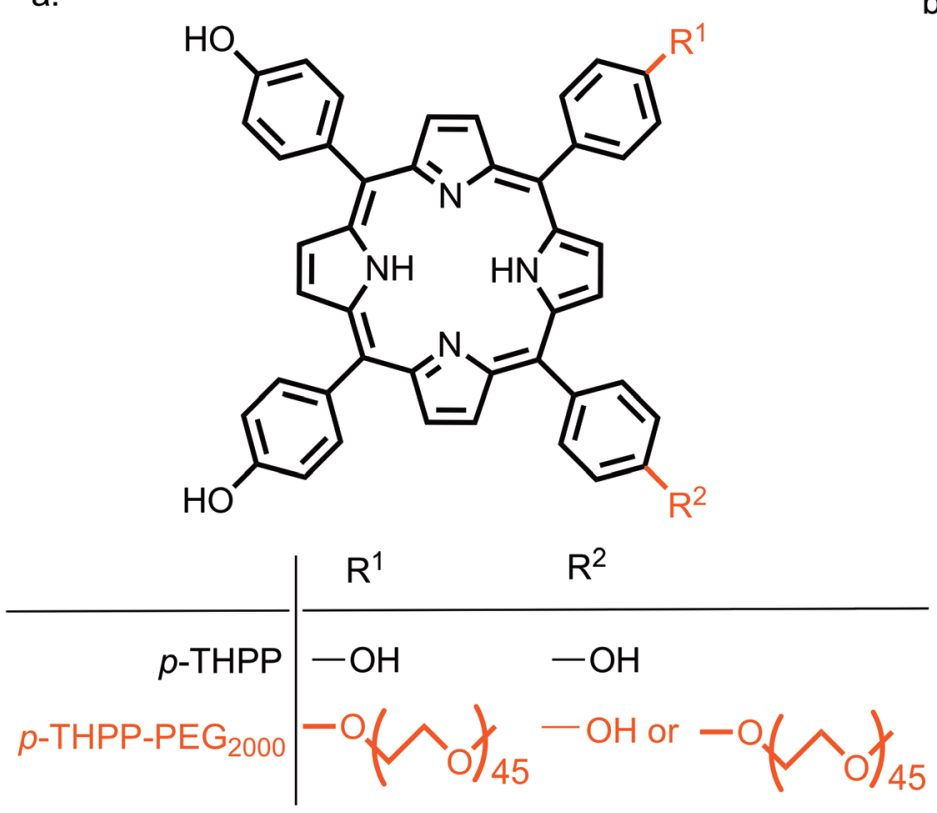

b.

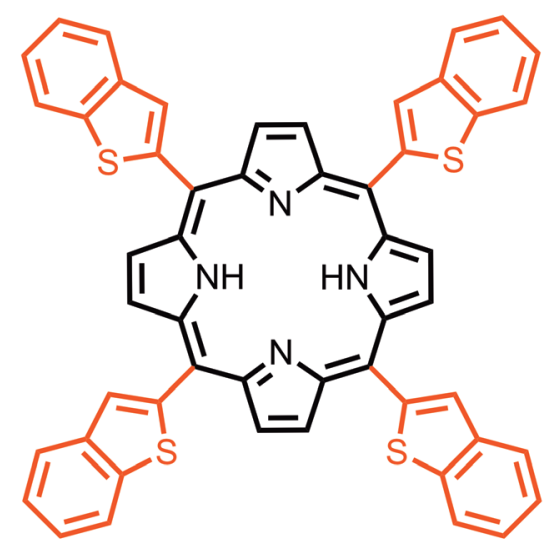

Figure 4 - a. Structure of 5,10,15,20-tetrakis(4-hydroxyphenyl)porphyrin ( $p$-THPP) and of the derivatives substituted by PEG $_{2000}$; b. Structure of 5,10,15,20-tetrakis(benzo[b]thiophene)porphyrin.

145), and compared with free $p$-THPP. The results showed that both pegylation and incorporation in the sterically stabilized liposomes were able to reduce efficiently the dark cytotoxicity of the parent porphyrin. Moreover, the pegylated porphyrin dissolved in culture medium was less readily taken-up by cells than the porphyrin encapsulated in liposomes, probably due to formation of large polymeric clusters. Additionally, the liposomal formulation showed higher photocytotoxicity than p-THPP-PEG ${ }_{2000}$ towards both cell lines, but the overall phototoxicity efficiency was dependent on the type of the cancer cell line (Nawalany et al. 2009).

Another study concerning the use of a synthetic porphyrin was recently reported by Nam et al. (Nam et al. 2017). The hydrophobic 5,10,15,20-tetrakis(benzo[b]thiophene)porphyrin (Figure $4 \mathrm{~b}$ ) was incorporated into various compositions of liposomes (DOPC, DPPC, phosphatidylserine and phosphatidylinositol, Figure 3b) and the PDT efficacy of the liposomal compositions was evaluated against MCF-7 cells (Nam et al. 2017). Although all liposomal compositions displayed photodynamic efficiency, the one prepared with DOPC was the most promising. After irradiation, this formulation was also the one that exhibited higher intracellular ${ }^{1} \mathrm{O}_{2}$ generation, the main responsible of cancer cell death

In a research work carried out in 2014 by Temizel et al. (Temizel et al. 2014), it was studied the photodynamic activity of protoporphyrin IX (PpIX) (Figure 2) bearing lipophilic oleylamine arms (PpIX-Ole) (Figure 5) before and after being encapsulated into 1,2-dioleoyl-sn-glycerophosphatidylcholine (DOPC) liposomes (Figure $3 b)$. The photodynamic studies of the liposomal materials were performed in the presence of cancer cell lines HeLa and AGS, under irradiation with UV light $375 \mathrm{~nm}(10 \mathrm{~mW})$. It was found that both PpIX-Ole-DOPC and PpIX-Ole are much more effective than the non-functionalized PpIX and the results were due to the drug delivery characteristic of the liposome, which showed an effective role in endocytosis. In the same study it was also reported 


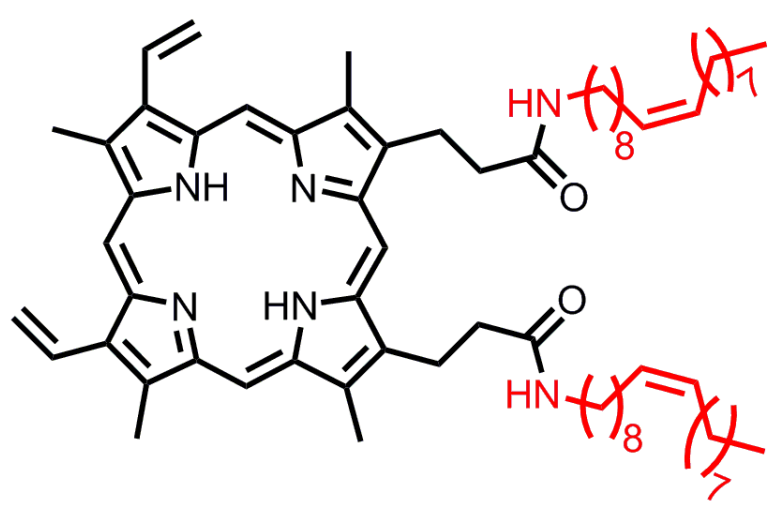

Figure 5 - Structure of Protoporphyrin IX functionalized with lipophilic oleylamine.

that under light conditions, liposomal PpIX-Ole is able to induce more apoptosis in AGS cells than in HeLa cells, being this situation related to the permeability of the cells (Temizel et al. 2014).

\section{SILICA NANOPARTICLES}

As it was mentioned earlier, some PSs can aggregate and consequently the effectiveness of photoinactivation can be affected (Darwent et al. 1982). Taking this aspect in consideration, several studies concerning biomedical applications have been focused on the incorporation of PSs into silica NPs (SiNP) once they are suitable carrier for bioactive molecules by preventing or minimizing the aggregation phenomena or their degradation under physiological conditions (Couleaud et al. 2010, Lin et al. 2011, Oluwole and Nyokong 2017, Tang and Cheng 2013). In clinical field, SiNPs are used as cell markers (Huang et al. 2005, Lin et al. 2006, Wu et al. 2008), drug and gene delivery platforms (Lu et al. 2007, Tsai et al. 2008), enzyme adsorption and immobilization (Popat et al. 2011), and they are also able to internalize into cells per si (Huang et al. 2005, Lin et al. 2006, Wu et al. 2008). For application in PDT, silica based NPs such as organically modified silica (ORMOSIL), mesoporous silica NPs (MSiNP) and hollow SiNPs (HSiNP) are commonly employed. These SiNPs are especially suitable for PDT because they are vehicles of great chemical inertness, immune to $\mathrm{pH}$ variations, structurally stable, transparent to light and allow to keep the attached PS in monomeric form, preventing self-aggregation in physiologic conditions. Besides that, molecular oxygen and ${ }^{1} \mathrm{O}_{2}$ can diffuse in and out through the shell of SiNP (Chouikrat et al. 2012, Stallivieri et al. 2016). Moreover, SiNPs can be easily prepared from a variety of precursors and synthetic routes in different size, shape and porosity and its surface can be decorated with several tumor-cell targeting vectors, such as PEGs, antibodies, peptides, glycosides among several other possibilities (Couleaud et al. 2010, Lucky et al. 2015, Piao et al. 2008).

ORMOSIL based NPs have been extensively used due to their flexible hydrophobic/hydrophilic properties, which can overcome the problem associated with the degree of hydrophobicity of the PS. Moreover, ORMOSIL can possess functional groups added to the surface that make these SiNPs promising vectors for PDT applications (Couleaud et al. 2010). For instance, Ohulchanskyy et al. were able to prepare ORMOSIL NPs with a PS molecule covalently incorporated into the SiNP aiming to minimize the PS release during systemic circulation (Ohulchanskyy et al. 2007). In this study, the precursor for ORMOSIL with the linked PS iodobenzylpyropheophorbide (Figure 6) was first prepared to promote its co-precipitation with the ORMOSIL precursor vinyltriethoxysilane. The PS-conjugated to ORMOSIL and an ORMOSIL encapsulated PS were tested against two tumor cells Colon-26 and RIF-1 cell lines. The results demonstrated that in addition to the preservation of the photophysical properties by the PS-conjugated ORMOSIL, an avidly uptake was observed by this conjugate and a significant phototoxicity in treated cells upon light irradiation. Moreover, the authors highlighted the fact that the presence of the iodine atom on the PS molecule allows its chemical replacement by a radiolabeled iodine 


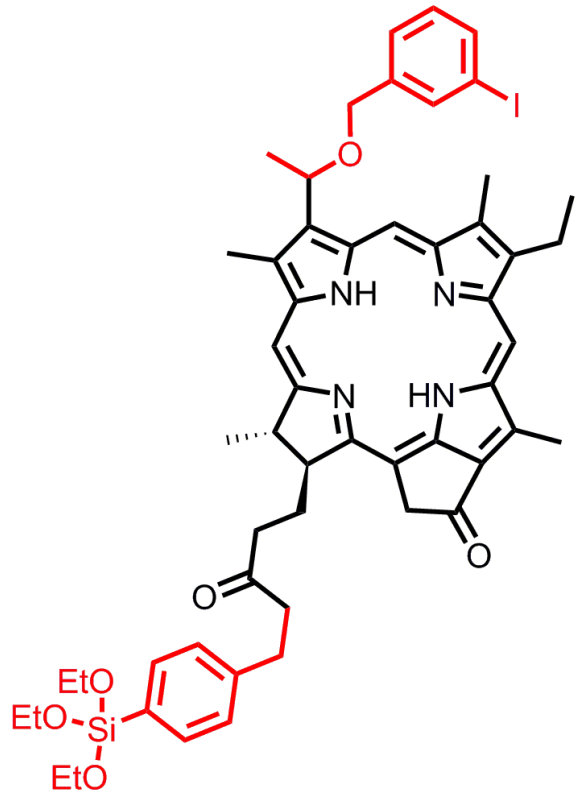

Figure 6 - Structure of the precursor for ORMOSIL with the linked PS 3-iodobenzylpyropheophorbide.

atom (e.g. I-124, I-125, etc.), thus converting these NPs in contrast agents for PET/SPECT imaging while preserving their therapeutic functionality (Ohulchanskyy et al. 2007). Similar photodynamic behavior was observed by other research groups involving other PSs covalently linked or encapsulated in ORMOSIL NPs (Tang et al. 2007).

Managa et al. reported the covalent attachment of $\mathrm{Zn}(\mathrm{II}), \mathrm{Ga}(\mathrm{III})$ and $\mathrm{Si}(\mathrm{IV})$ complexes of 5-(4-(4-carboxyphenyl)oxyphenyl)-10,15,20triphenylporphyrin (Figure 7) by an ester linkage to SiNPs in the presence of the polymeric matrix Pluronic 127. Although the ${ }^{1} \mathrm{O}_{2}$ quantum yield suffered a slightly decrease upon conjugation, the photodynamic efficiency of the materials was improved when compared with the nonincorporated complexes and the best results were obtained with the $\mathrm{Zn}$ (II) derivative (Managa et al. 2016).

The efficacy of protoporphyrin IX (Figure 2) encapsulated in SiNPs of different sizes (10, 25 and $60 \mathrm{~nm}$ ) was evaluated in vitro against six cancer cell

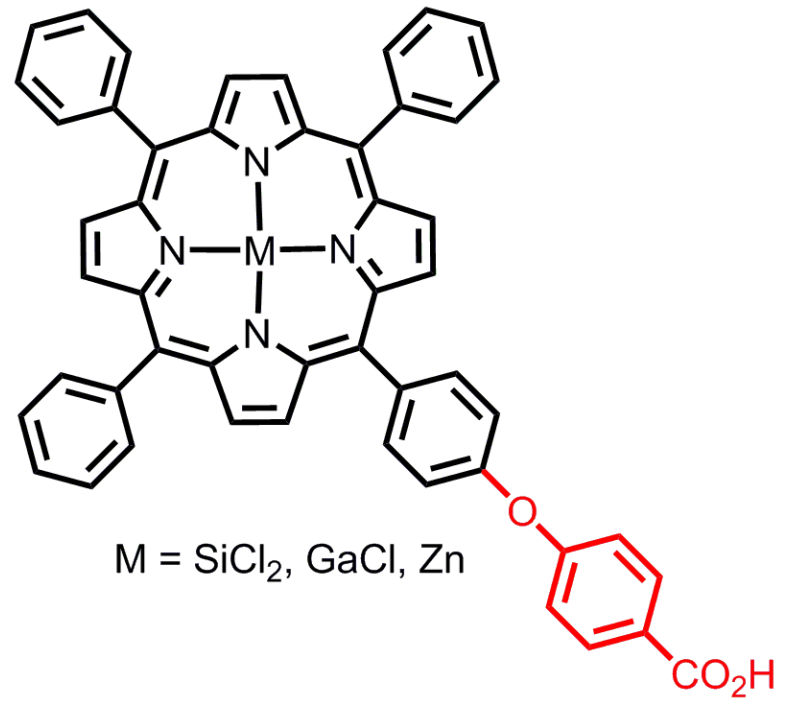

Figure 7 - Structure of 5-(4-(4-carboxyphenyl)oxyphenyl)10,15,20-triphenylporphyrin complexed with $\mathrm{Zn}(\mathrm{II}), \mathrm{Ga}(\mathrm{III})$ and $\mathrm{Si}(\mathrm{IV})$ used to link to pluronic SiNPs.

lines (colon cancer cell lines HCT-116 and HT-29, breast cancer cell lines MCF-7 and MDA-MB-231, epidermoid cell line A431 and the lymphoblastoid cell line LLBC37) by Simon et al. in 2010 (Simon et al. 2010). The authors observed that for all the cell lines a better efficiency of photosensitization was reached when the PS was incorporated in the NPs. In the in vivo tests performed in HCT116, A549 and glioblastoma multiforme tumor-bearing mice, the uptake of protoporphyrin IX encapsulated in SiNP was high and its accumulation in skin was markedly lower when compared with tumor (Simon et al. 2010).

Gianotti et al. (Gianotti et al. 2016) used mesoporous SiNPs (MSiNPs) to covalently conjugate verteporfin (Figure 2), a clinically approved PS of second generation (Figure 8). The conjugates were prepared with three different concentrations of verteporfin (nominal loading of 10,40 and $100 \mathrm{mg} / \mathrm{g}$ ), and the highest photodynamic efficiency was obtained with the intermediate loading system $(40 \mathrm{mg} / \mathrm{g})$. The biological evaluation 
of this conjugate was assessed in HeLa cells after 4 $\mathrm{h}$ of incubation and the results showed that the cell viability was dramatically reduced after $60 \mathrm{~s}$ of red light irradiation (Gianotti et al. 2016).

Zhang et al. (Zhang et al. 2016) constructed a drug delivery system also based on MSiNPs for the co-delivery of cisplatin and chlorin $\mathrm{e}_{6}$ (Figure 2). The principal aim of the study was to circumvent the cisplatin resistance problem by combining the chemotreatment with PDT. The new drug delivery system was tested in lung cell lines non-cisplatin resistant (A549) and cisplatin resistant (A549R). The study showed that the MSiNPs bearing cisplatin and chlorin $\mathrm{e}_{6}$ were efficiently internalized by cells through endocytosis and released into cytoplasm resulting on remarkable high cellular levels of ROS, after $660 \mathrm{~nm}$ light irradiation $\left(10 \mathrm{~mW} / \mathrm{cm}^{2}\right)$ (Zhang et al. 2016). This combined chemo-photodynamic therapy achieved very efficient anticancer activity against cisplatin-resistant A549R lung cancer cells with much lower IC50 values $(0.53 \mu \mathrm{M})$ that cisplatin alone $(25.1 \mu \mathrm{M})$.

Chen et al. (Chen et al. 2016b) followed a slightly different approach to build nanoplatforms based on MSiNPs to deliver the bioreductive prodrug tirapazamine (TPZ) and the $\mathrm{Gd}^{3+}$ complex of tetrasulfonated porphyrin $\left(\mathrm{TPPS}_{4}\right)$ (Figure 2). It was expected that the cytotoxicity of TPZ to hypoxic cells, could complement the PDT action, due to tumor hypoxic environment intensified by the photochemical reaction during PDT. The nanoplatforms were prepared using negatively charged per- $O$-methyl- $\beta$-cyclodextrin-graftedhyaluronic acid (HA-CD) and the $\mathrm{Gd}^{3+}$ complex of 5,10,15,20-tetrakis(4-sulfonatophenyl)porphyrin alternatively deposited onto TPZ-MSiNPs via a layer-by-layer (LbL) assembly strategy (Figure 9).

The efficacy of the drug delivered platform was assessed on three cell lines (Squamous cell carcinoma cell line SCC-7, Human breast adenocarcinoma cell line $\mathrm{MCF}-7$ and African green monkey kidney fibroblast cells COS-

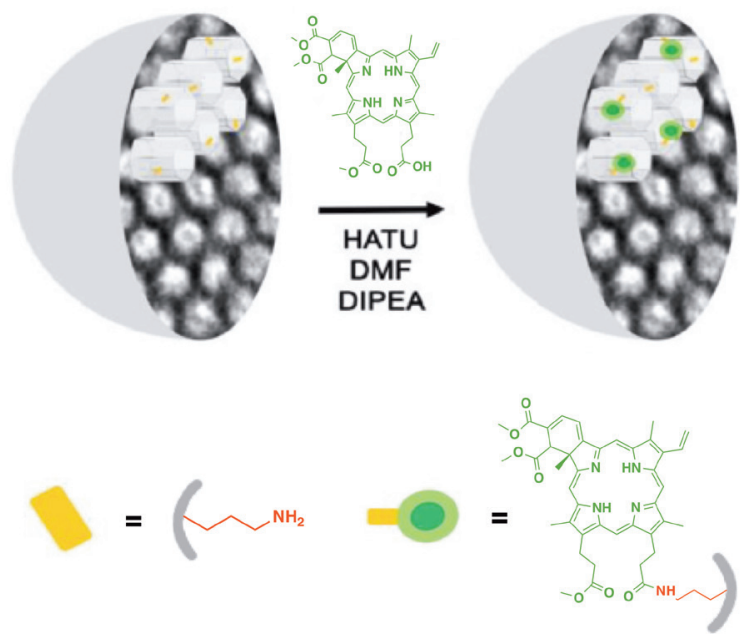

Figure 8 - Schematic representation of the synthetic procedure used to obtain Verteporfin-MSiNPs. Reproduced from (Gianotti et al. 2016) with permission of John Wiley and Sons.

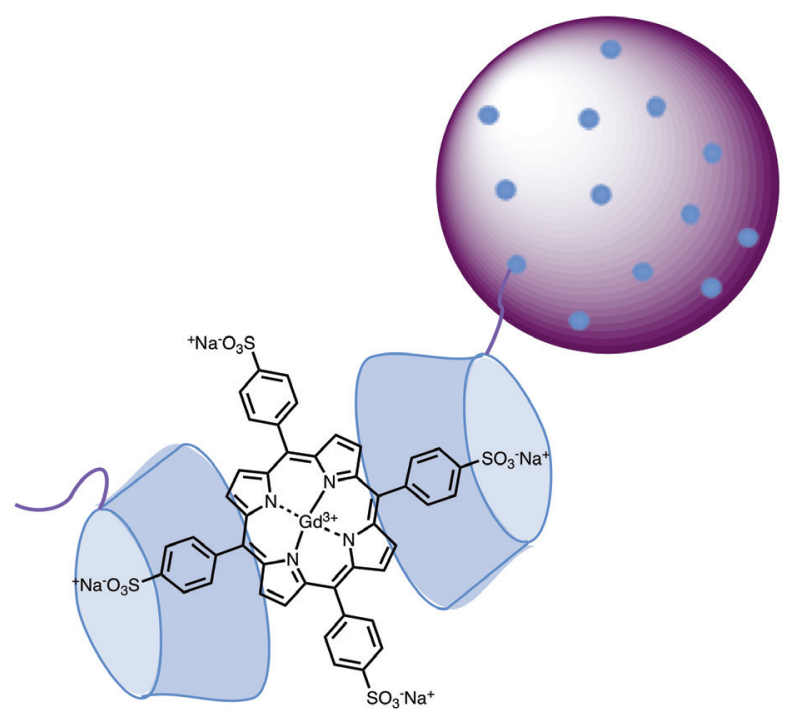

Figure 9 - The theranostic nanoplatform of TPPS 4 on TPZMSiNPs.

7) and also in vivo using $\mathrm{BALB} / \mathrm{c}$ nude mice inoculated in the back hind leg with SCC-7 cells. The biological assessment studies showed a preferential accumulation of the nanoplatform in the tumor site and a significant inhibition of tumor progression by this combined action of PDT and bioreductive chemotherapy (Chen et al. 2016b). The enhanced synergistic effect was also intuitively confirmed by the final average tumor weight and the corresponding tumor images. 
Teng et al. (Teng et al. 2013) selected also MSiNPs as the drug deliver platform for their PDT studies. The authors loaded PpIX (Figure 2) in MSiNPs sensitized with fluorescein isothiocyanate (FITC) and with a phospholipid derivatized with folate. The prepared deliver platform enhanced the in vitro phototoxicity against HeLa cells and diminished dark toxicity when compared with the free PpIX. The in vivo study performed on subcutaneous melanoma in nude mice inoculated with B16F10 cells, also presented the ability of this nanocarrier system to mitigate nearly $65 \%$ of tumor growth (Teng et al. 2013). It was also commented that the co-loading of PpIX and FITC in the nanoPDT system provided an insight into the therapeutic mechanism by tracking their fluorescent emissions.

Taking advantage that some materials can convert absorbed lower-energy photons (with less energy than the singlet energy level of molecular oxygen) to higher-energy photons through excitation with multiple photons process, $\mathrm{Xu}$ et al. (Xu et al. 2016) constructed a nanoplatform based on mesoporous silica coated with NaYF4:Yb/Er and then soaked with an aqueous solution of vitamin $\mathrm{B}_{12}$ (the selected PS), for $24 \mathrm{~h}$. The biological results obtained showed that the nanoplatform containing vitamin $\mathrm{B}_{12}$ exhibited a significant photodynamic effect on human breast cancer cell line (MDAMB-231) under near-infrared irradiation (980 nm) (Xu et al. 2016).

The high capacity of hollow SiNPs (HSiNPs) to load PSs into their cavities was also considered in several publications once the required PS concentrations in the tumoral region can be attained faster when compared with other nanoplatforms. For instance, Deng et al. demonstrated the superiority of Photosan (Figure 2) loaded into HSiNPs when compared with the free PS in the photodamage of cholangiocarcinoma cells QBC939 (Deng et al. 2013b). Parameters such as photostability and generation of ${ }^{1} \mathrm{O}_{2}$ were significantly enhanced by the encapsulation and also the concentration of the PS into the cells (Deng et al. 2013b).

A similar approach was developed by Peng et al. (Peng et al. 2013) to load the hydrophobic free phthalocyanine (Figure 2) into HSiNPs (PcHSiNPs). The authors tested the effectiveness of this platform in vitro and in vivo by combing nearinfrared photodynamic therapy and photothermal therapy. In fact, the intratumoral injection of PcHSiNPs in BALB/c mice, led to the elimination of the S180 murine sarcoma, after laser irradiation $\left(730 \mathrm{~nm}, 1.5 \mathrm{~W} / \mathrm{cm}^{2}\right)$ without any significant toxic effects (Peng et al. 2013). The successful eradication was justified by the dual PDT and photothermal properties of Pc-HSiNPs

Tao et al. (Tao et al. 2013) also selected porous HSiNPs to construct a nanoplatform to deliver the tetrasulfonated aluminum phthalocyanine sensitizer (Figure 10). The loading of the phthalocyanine was performed in porous NPs with the surface grafted with polyamidoamine (PAMAM) dendrimer of third-generation in which was posteriorly attached gluconic acid (a polyhydroxylic acid) to tune the surface charge close to neutral (Figure 10). The therapeutic potential of this nanocarrier was evaluated in vitro using MCF-7 cells. The high loading and the retarded pre-release of the PS were justified considering the inherent structural features of the carrier and the functionalized outer layer composed by a large number of amino groups. These HSiNPs showed very good ${ }^{1} \mathrm{O}_{2}$ generation ability and were also capable of inducing significant damage in tumor cells after irradiation with red light $\left(670 \mathrm{~nm}, 8 \mathrm{~mW} / \mathrm{cm}^{2}\right)$. In fact, a significant cell death was observed for the loaded PS in HSiNPs $(70 \%$ at $5.0 \mu \mathrm{M} ; 82 \%$ at $10 \mu \mathrm{M})$ as compared with free phthalocyanine tetrasulfonate $(17 \%$ at $5 \mu \mathrm{M}$; $35 \%$ at $10 \mu \mathrm{M}$ ) (Tao et al. 2013). 


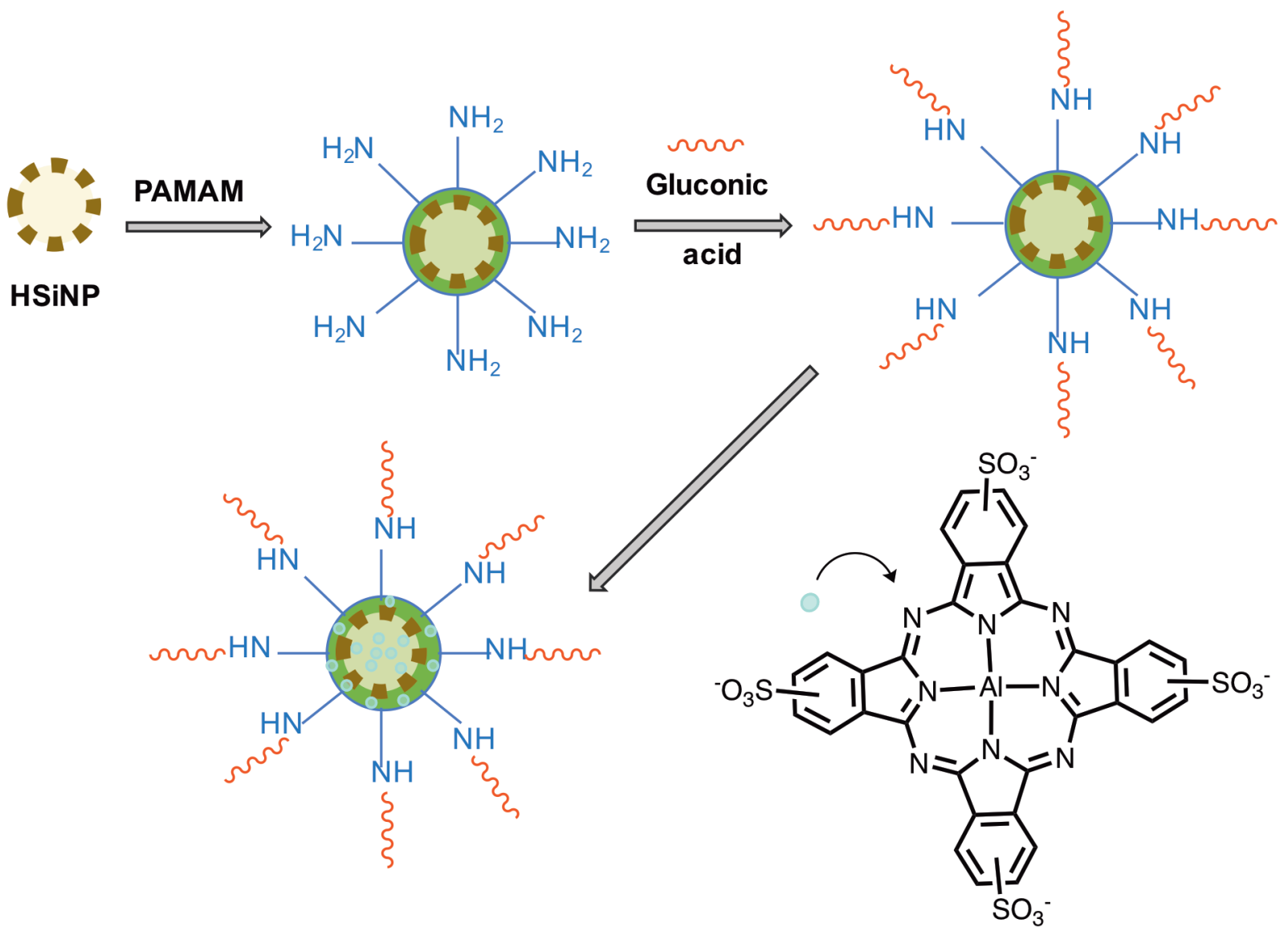

Figure 10 - Schematic representation of the preparation of a new nanoplatform to deliver the tetrasulfonated aluminum phthalocyanine adapted from (Tao et al. 2013).

\section{GOLD NANOPARTICLES}

Metal NPs are also attracting a special attention from the scientific community due to their versatility in diverse areas as engineering, medicine, chemistry, physics and biology (Jana and Pal 2007, Marambio-Jones and Hoek 2010, Dos Santos et al. 2014, Sanvicens and Marco 2008). The general mechanism of metal NP action has not been fully understood, although it is known that it is necessary to obtain the correct dimensions of the metal NPs to avoid agglomeration, which will significantly reduce their biological effectiveness. Among all the metal NPs, gold NPs (AuNPs) have received particular attention, due to a combination of distinctive properties, which led them to multiple applications such as labeling, delivery, heating, imaging and sensing (Biju 2014, Castilho et al. 2015, Gupta et al. 2013, Oo et al. 2012). Specifically, these NPs owing to their biocompatibility, size, unique surface and also optical properties have recently earned significant attention in PDT (Pasparakis 2013, Amini et al. 2013, Sherwani et al. 2015). The presence of some functional groups such as thiol, amino and cyano, with high chemical affinity for AuNPs, confer them colloidal stability (Zeng et al. 2011). Additionally, the functionalization of AuNPs with biomolecules such as lipids, proteins, oligonucleotides or with PS molecules can improve their features (Castilho et al. 2015, Shi et al. 2004). In fact, the conjugation of PSs on the surface of AuNPs may increase the PDT efficacy due to an enhanced electromagnetic field as 


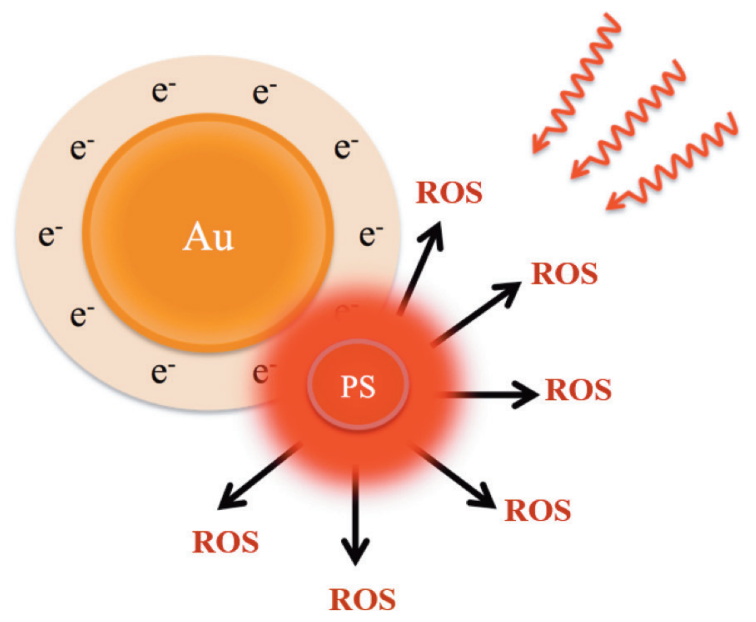

Figure 11 - Plasmonic AuNP. The local electric field caused by conductance electrons potentiates the optical field near the surface and enhances the fluorescence or photoactivity of the attached PS.

a result of the localized surface plasmon resonance of AuNPs upon light exposure. This situation will then lead to an efficient activation of the PS (an enhanced PS excitation rate) and an improvement of ROS production (Figure 11) (Huang and Hasan 2014, Oo et al. 2012, Amini et al. 2013).

In 2008, Cheng et al. (Cheng et al. 2008) demonstrated that pegylated AuNPs were highly effective drug vectors to deliver hydrophobic drugs for PDT like silicon phthalocyanine (Figure 12 a). These biocompatible cages showed good and stable dispersion in aqueous solution allowing the hydrophobic drug to reach with high efficiency the location of PDT action, as it was demonstrated by the in vivo studies in cancer-bearing mice. The pegylated AuNPs system took less than $2 \mathrm{~h}$ to deliver the silicon phthalocyanine when it was conjugated with AuNPs, compared to 2 days for the free drug (Cheng et al. 2008). Similar results were obtained by Camerin et al. (Camerin et al. 2010), which evaluated the pharmacokinetic and phototherapeutic properties of a zinc(II)phthalocyanine disulfide free and bound to AuNPs for the treatment of a sub-cutaneous implanted amelanotic melanoma in a murine tumor model
(Figure 12b). Once again, the data showed that the use of these AuNPs for the delivery of hydrophobic PS, such as phthalocyanines, significantly enhanced the PDT efficacy, even though suitable approaches should be developed in order to limit the persistence of the AuNPs associated PS in important organs such as liver and spleen (Camerin et al. 2010).

Zhao et al. (Zhao et al. 2013a) reported the preparation of a theranostic platform based on the conjugation of a biodegradable copolymer with AuNPs to deliver pheophorbide $a$ (Figure 2) linked to the side chain of the copolymer by an imine bond (Figure 13a). The phototoxicity of the hydrophobic pheophorbide $a$ and of the AuNPPS was investigated against HeLa cells upon irradiation at $670 \mathrm{~nm}$. This AuNPs-PS platform showed not only an enhanced cellular uptake and phototoxicity against HeLa cells when compared to free pheophorbide $a$, but also a strong fluorescence signal considering their use in diagnostic imaging. The authors justified the higher efficiency of AuNP-PS to the fact that NPs are improving the PS solubility in the aqueous environment and increasing ${ }^{1} \mathrm{O}_{2}$ quantum yield. The replacement of the pheophorbide $a$ by verteporfin (Figure 2) on the AuNP nanoplatform (Figure 13b) revealed even better uptake efficiency by HeLa cells and a marked photocytotoxicity when compared with the free PS (Zhao et al. 2016). The developed nanoplatforms possess drug release properties, which can be triggered by the $\mathrm{pH}$ and consequently, overcome the intracellular barriers of endosomal or lysosomal membranes that prevent the drugs to arrive to their targets (Zhao et al. 2013b, 2016). While stable at physiological $\mathrm{pH}$ values, the PS conjugated to the side chain of the copolymers, via an imine linkage can be released at lower $\mathrm{pH}$ values (4.0-6.0) like those found in the vicinity of tumor tissues or within endo/lysosomal compartments. In the reported example, strong fluorescence signals around the nucleus and in the cytoplasm of cells were observed for this nanoplatform which was confirmed by 


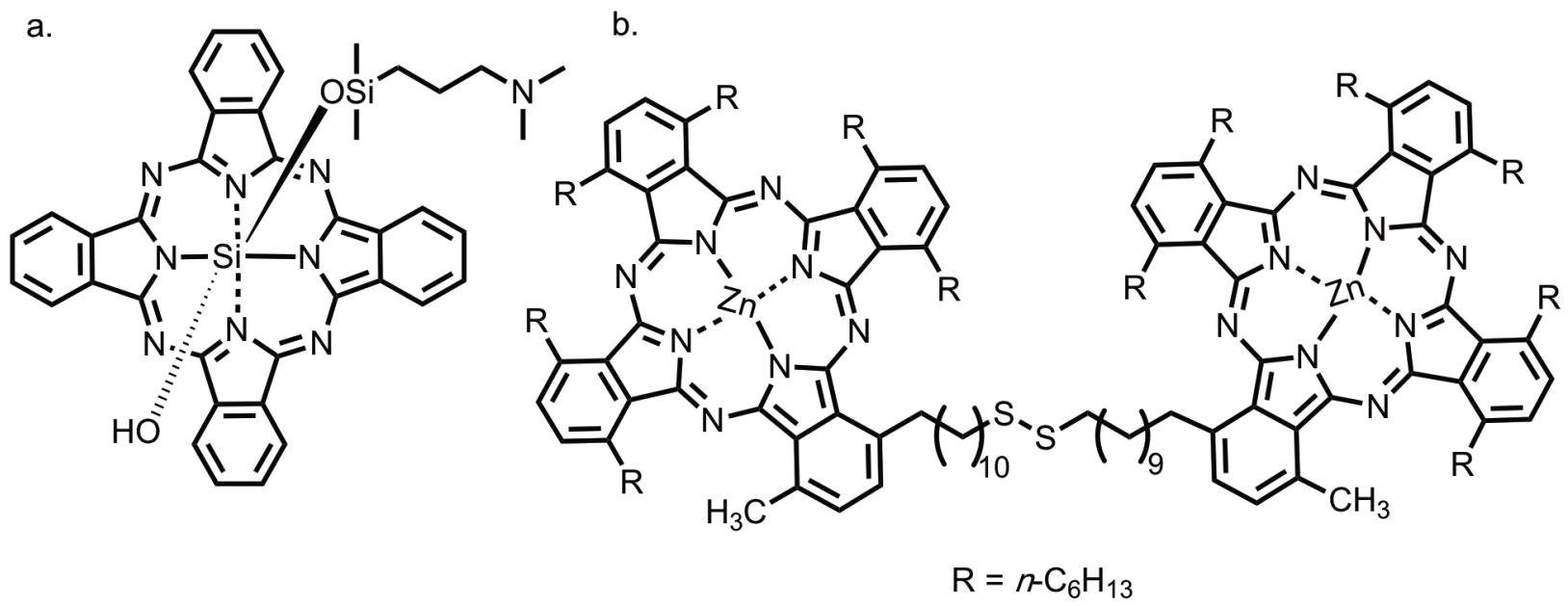

Figure 12 - Structures of a. a silicon phthalocyanine, and b. a $\mathrm{Zn}(\mathrm{II})$-phthalocyanine disulfide.

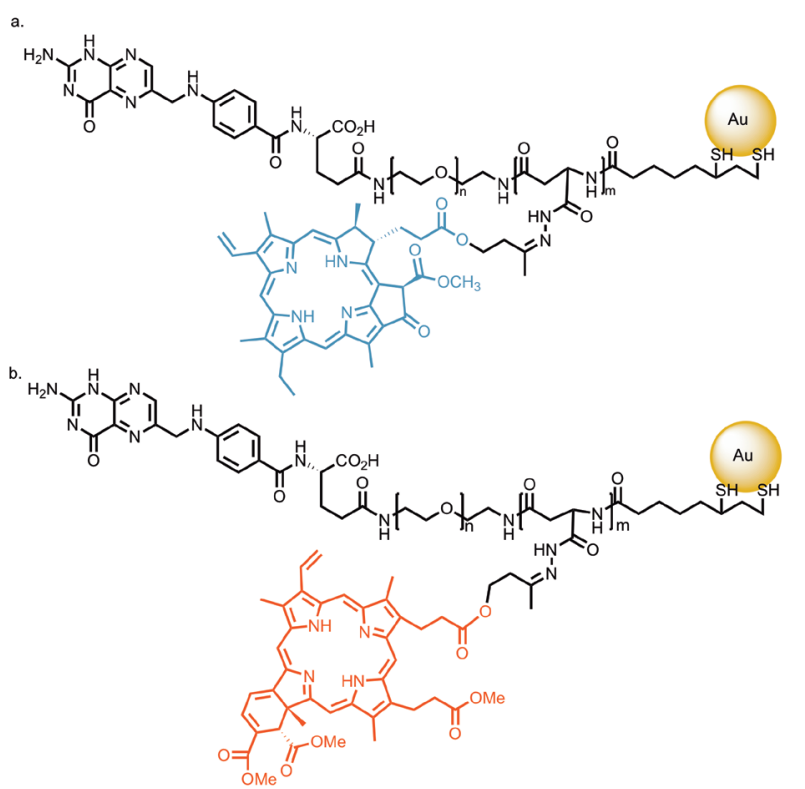

Figure 13 - Structure of a biodegradable block copolymerAuNP conjugated with a. Pheophorbide $a$ and $\mathbf{b}$. Verteporfin.

the cellular uptake by HeLa cells $(98.62 \%)$ when compared to free verteporfin molecules (18.86\%), and consequently by its marked photocytotoxicity (Zhao et al. 2016).

Vieira et al. (Vieira et al. 2017) also reported the functionalization of AuNPs with a chlorophyll derivative. The authors selected chlorin $\mathrm{e}_{6}\left(\mathrm{Ce}_{6}\right)$ (Figure 2) covalently linked through an amide bond to a thiourea molecule to perform the conjugation to AuNPs, and tested the photodynamic efficacy of the resulting nanostructures against human breast carcinoma cells (MDA-MB-468). The results showed that the photocytotoxicity of $\mathrm{Ce}_{6}$-AuNP was higher than $\mathrm{Ce}_{6}$ alone for MDA-MB-468 cells after irradiation with red light at $660 \mathrm{~nm}$, but quite similar to the simple mixture of $\mathrm{Ce}_{6}$ with AuNPs. The authors commented that $\mathrm{Ce}_{6}$-AuNPs complex should be more efficient than the $\mathrm{Ce}_{6}$ mixture with AuNPs for in vivo applications because due to the many variables of the body circulation system there is no guaranty that AuNPs will be available in the same irradiated area of the activated $\mathrm{Ce}_{6}$ (Vieira et al. 2017)

The possibility to prepare a multicomponent system based on water-soluble AuNPs for PDT was recently reported by Peron et al. (Penon et al. 2017). This group constructed a nanoplatform of AuNPs (PS-AuNPs-PEG-Ab) containing a porphyrin derivative as $\mathrm{PS}$ and a polyethyleneglycol derivative linked to an anti-erbB2 antibody to specifically target the erbB2 receptors overexpressed on the surface of SK-BR-3 breast cancer cells (Figure 14); the presence of the thiol groups in both ligands allowed a suitable functionalization of the AuNP. This conjugate not only proved to be successful in the production of ${ }^{1} \mathrm{O}_{2}$ but also in the induction of cell death of SK-BR-3 breast cancer cells after 
PDT irradiation. Besides the high level of cellular uptake, changes in the cellular morphology were detected and cell membrane damages were confirmed after irradiation of the SK-BR-3 cancer cells when incubated with the PS-AuNP-PEG-Ab conjugate (Penon et al. 2017).

In 2016, Ferreira et al. considered the use of two different shapes (spheres and rods) of gold nanostructures to prepare a colloidal hybrid system with the cationic derivative of 5,10,15,20-tetrapyridylporphyrin (Figure 2) to be used in PDT (Ferreira et al. 2016). Based on electron paramagnetic resonance (EPR) experiments in combination with spin trapping to detect ROS, the authors concluded that the hybrid system consisting of gold nanorods (AuNR) and the cationic porphyrin is far more efficient than the isolated components. This synergetic efficiency was explained by a rapid energy transfer between the AuNR and the porphyrin producing a large amount of ${ }^{1} \mathrm{O}_{2}$ followed by its conversion into hydroxyl radicals $\left(\mathrm{OH}^{\bullet}\right)$. On the other hand no synergetic effect was observed with the spherical AuNP; probably the field enhancement and the electrostatic attraction between the components of this hybrid system were not so efficient in the production of ROS (Ferreira et al. 2016).

\section{POLYMERIC MICELLES}

Polymeric micelles (PMs) are one of the most studied drug nanocarriers that are being used in diagnosis and in the pharmacotherapy of numerous diseases. These vehicles are composed of amphiphilic polymers that self-assemble into nanostructures with sizes ranging between 10 and $200 \mathrm{~nm}$ (Kwon 2003, Li and Huang 2008, Tong and Cheng 2007, Torchilin 2007). This thermodynamically driven process occurs above a copolymer determined concentration, commonly known as critical micellar concentration (CMC) (Croy and Kwon 2006, Riess 2003). Thus, PMs contain an inner hydrophobic core, in which poorly-water soluble-drugs can be entrapped, and an outer hydrophilic shell, which forms the corona (Figure 15) (Kwon 2003, van Nostrum 2004, Tong and Cheng 2007, Torchilin 2007). PMs are emerging as attractive nano-sized drug delivery systems, because they provide increased solubility and stability of hydrophobic drugs (Kahraman et al. 2015, Moretton et al. 2014), and also due to their in vivo benefits when compared to the free drug (Attia et al. 2011).

Typically, physical entrapment is achieved by electrostatic interaction between drug and polymer (the resulting particles are called polyion complex micelles) by dialysis from an organic solvent (Kakizawa and Kataoka 2002), or by oil in-water emulsion procedures (van Nostrum 2004). As a solubilizing agent for hydrophobic drugs, PMs possess great benefits over low molecular weight surfactants, as a result of the higher stability of the micelles. Their higher stability is due to the typically very low CMC of polymeric surfactants (Adams et al. 2003), meaning that PMs are resistant to dilution effects, upon for instance intravenous administration of the drug formulation (van Nostrum 2004). Another important feature of PMs is their small and uniform size. As aforementioned, particle sizes can go down to the order of $10 \mathrm{~nm}$ for non-loaded polymeric micelles. However, this size is still large enough to achieve passive targeting to tumors and inflamed tissues (Maeda et al. 2000). Additionally, the hydrophilic corona of PMs may prevent interaction with blood components. This situation, as well as their reduced size, will prevent recognition by proteins and macrophages, thus achieving long circulation times in the blood stream (Kwon et al. 1994). Moreover, it is possible to adjust the peripheral chain ends of the PMs with targeting ligands in order to try to accomplish active targeting and/or $\mathrm{pH} /$ temperature responsive nanocarriers (Vinogradov et al. 1999, Yasugi et al. 1999). Therefore, the outer hydrophilic corona 


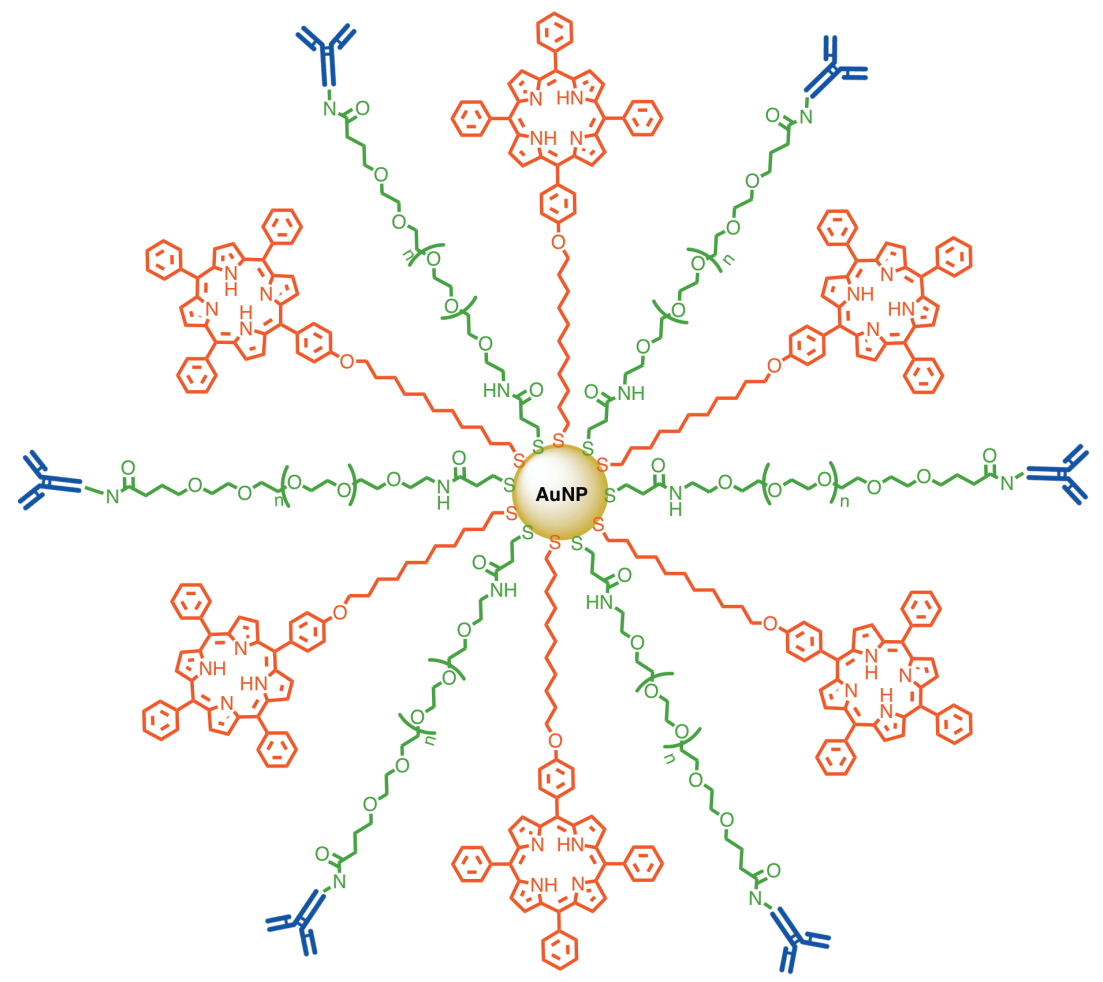

Figure 14 - Schematic representation of the PS-AuNP-PEG-Ab conjugates. AuNP functionalized with the thiolated porphyrin derivative ligand (red) and the thiolated polyethylene glycol derivative ligand (green) bound to an anti-erbB2 antibody (blue) adapted from (Penon et al. 2017).

can be functionalized with several moieties, such as folate, monoclonal antibodies, monosaccharides (mannose, glucose, fructose), among others (Torchilin 2001, 2002, Zhang et al. 2014). When the PMs have reached their targets and for the release of the drugs, degradable or stimuli-responsive micelles have been developed (Katayama et al. 2001, Kumar et al. 2001, Neradovic et al. 2001, Kakizawa et al. 1999). The role of polymeric micelles to improve the efficiency of several PS in PDT treatment is shown in some recent works that will be discussed below.

For instance, Lamch et al. (Lamch et al. 2014) studied polymeric micelles based on a mixture of Pluronics P123 $\left(\mathrm{EO}_{20}-\mathrm{PO}_{65}-\mathrm{EO}_{20}, \mathrm{MW} 5800 \mathrm{Da}\right)$ and F127 $\left(\mathrm{EO}_{100}-\mathrm{PO}_{69}-\mathrm{EO}_{100}, \mathrm{MW} 12600 \mathrm{Da}\right)$ (Figure 16), in order to improve the photodynamic action of Photofrin (Figure 2) on drug resistant ovarian cancer cells (SKOV-3) and caspase-3 deficient breast cancer line (MCF-7/WT) (Lamch et al. 2014). The cells were treated with Photofrin in the free form and with Photofrin encapsulated in PMs and were then irradiated with red light (632.5 $\mathrm{nm}$ ) with a light dose of $12 \mathrm{~J} / \mathrm{cm}^{2}$ (irradiance of 10 $\mathrm{mW} / \mathrm{cm}^{2}$ ). The PMs containing Photofrin showed an efficient delivery inside the breast MCF-7/ WT (caspase-3 deficient) and ovarian SKOV3 (resistant to chemotherapy) cells and provided a desirable improved photodynamic activity and efficacy. The most significant results were obtained in the case of ovarian cancer, resistant to several cytotoxic drugs. Additionally, the low magnitude of hemolysis of human erythrocytes and the insignificant dark cytotoxicity in cancer cells demonstrated the high biocompatibility of Photofrin-loaded Pluronic micelles. The authors 


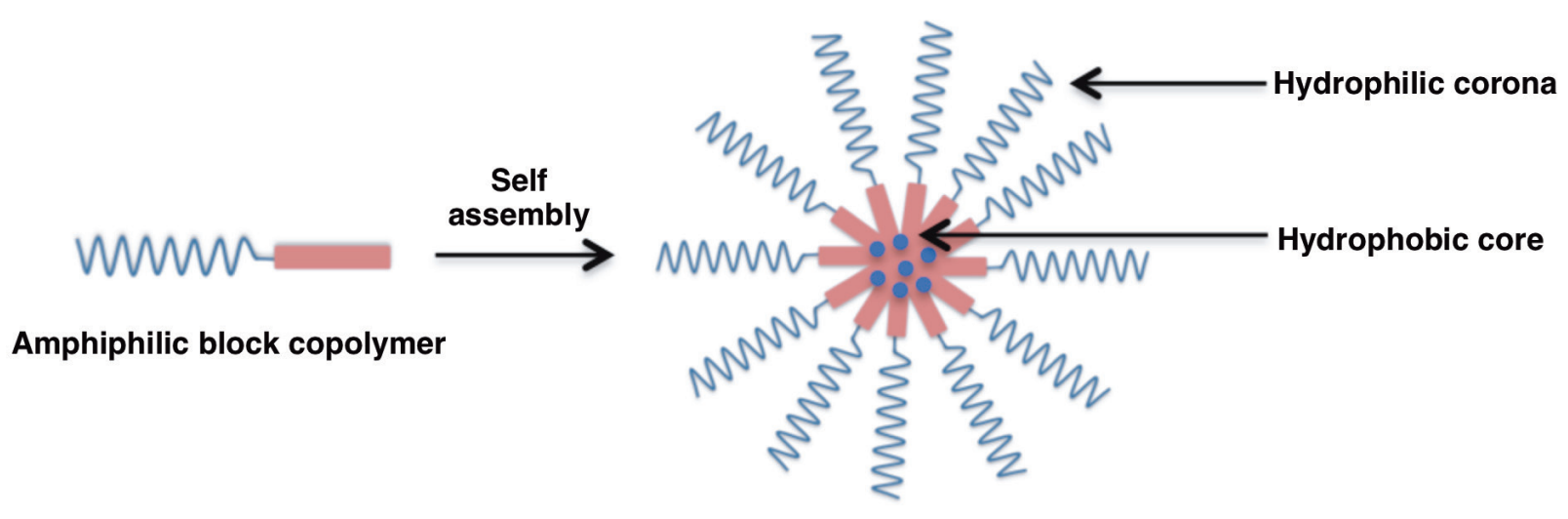

Polymeric micelle with PS

\section{MW Hydrophilic block}

Figure 15 - Schematic representation of the micelle formation and PS-loading of amphiphilic block copolymers in water.

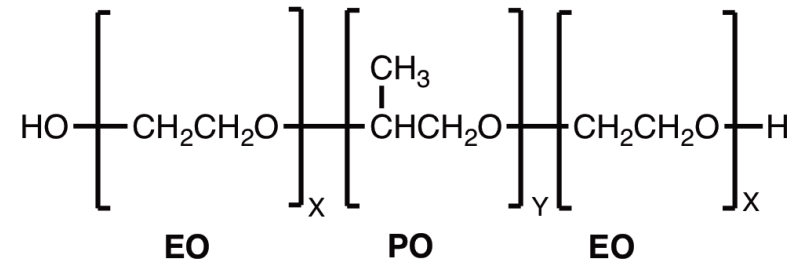

Figure 16 - Pluronic block copolymers. $\mathrm{X}$ is the number of ethylene oxide groups (EO) and $\mathrm{Y}$ is the number of propylene oxide groups (PO).

commented that the administration of Photofrin in micelles based on Pluronics (P123 and F127) could be extended to other resistant types of cancers since an increase in the cytotoxic effect after irradiation is easily achieved (Lamch et al. 2014).

The chloroaluminum phthalocyanine (Figure 2) was selected by Py-Daniel et al. (Py-Daniel et al. 2016) to be incorporated also into Pluronic F127 micelles (F127-PS) and the efficacy of this system was tested against A549 human lung carcinoma cells. The study showed that F127-PS was able to produce high concentration of ROS, mainly ${ }^{1} \mathrm{O}_{2}$. Moreover, this result was confirmed by in vitro assays that showed that F127-PS formulation, even at the tested PS loading of $0.1 \mu \mathrm{g} \mathrm{mL}^{-1}$, was very efficient in cell viability decreasing throughout light exposition (660 nm, LED light). Even though phthalocyanine molecules are extremely hydrophobic, their incorporation into optimized F127 micelles, provided their solubilization in aqueous/physiological environments, thus extending the range of applications of PDT with this PS (Py-Daniel et al. 2016).

Lamch et al. (Lamch et al. 2016) reported the incorporation of the zinc(II) phthalocyanine (Figure 2) in biodegradable and biocompatible micelles obtained from the block copolymer of methoxy poly(ethylene oxide) and poly(L-lactide) (Figure 17) (Lamch et al. 2016). The cellular uptake and photocytotoxicity studies on metastatic melanoma cells (Me45) showed that the obtained polymeric micelles was able to deliver efficiently the PS to cancer cells, with low toxic effect towards control keratinocytes, macrophages, and endothelial cells. Depending on the loading of the PS and the dose of irradiation the decrease on the tumor cell viability attained $31 \%$.

Another study involving the encapsulation of hydrophobic zinc(II) phthalocyanine was reported 


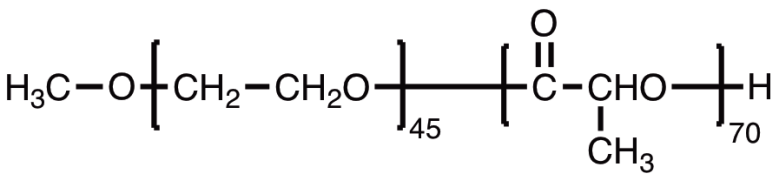

Figure 17 - Structure of block copolymer of methoxy poly(ethylene oxide) and poly(L-lactide).

by Debele et al. (Debele et al. 2017). The authors were able to synthesize $\mathrm{pH}$-sensitive micelles from heparin polysaccharide conjugated with 1,2-Distearoyl-sn-glycero-3-phosphoethanolamine (DSPE) and L-histidine (His) (Figure 18). The efficacy of these micelles was evaluated in HeLa cells, and the results showed that they respond to the low intracellular $\mathrm{pH}$ regions of cancer cells or in the endosome or lysosomes. After $96 \mathrm{~h}$ of incubation, the drug release studies presented about 91\% zinc(II) phthalocyanine release from micelles in acidic conditions ( $\mathrm{pH}$ 5.0) in comparison with $63 \%$ in physiological conditions ( $\mathrm{pH} 7.4$ ). Singlet oxygen detection showed that micelles prevented the aggregation of zinc(II) phthalocyanine and enhanced ${ }^{1} \mathrm{O}_{2}$ generation. On the other hand, phototoxicity experiments in HeLa cells showed that at higher concentrations $(>5 \mu \mathrm{M})$, zinc(II) phthalocyanine-loaded micelles were more cytotoxic than the free PS. In fact, more than $75 \%$ of HeLa cells were eradicated, which might be due to a better dispersion of the PS, thus diminishing its aggregation, and further enhancing ${ }^{1} \mathrm{O}_{2}$ generation. Hence, $\mathrm{pH}$-sensitive micelles appear as an encouraging carrier for hydrophobic zinc(II) phthalocyanine, improving PDT efficacy (Debele et al. 2017).

In a different study, Li et al. (Li et al. 2015) reported the encapsulation of Photofrin (Figure 2) in an amphiphilic chitosan derivative conjugated with deoxycholic acid groups (Figure 19) using a simple self-assembly method in phosphatebuffered saline solution (PBS). The efficacy of the resulting micelles as PSs was tested against human pancreatic cancer cells. It was referred that upon their incubation in the human pancreatic cancer cells, the micelles presented a higher fluorescence activity than the free PS and were able to generate higher levels of ROS under laser illumination; the opposite situation was observed before their cell incorporation. These photoactive micelles exhibited strong phototoxicity, which led to significant levels of apoptosis in the Panc-1 cells. Besides, the differences found in the morphologies of the cells treated with encapsulated and non-encapsulated Photofrin were in agreement with the stronger phototoxicity displayed by the micelles. The cells treated with non-encapsulated Photofrin underwent a gradual shrinkage whereas maintaining their pseudopodial structures. In contrast, the cells treated with the micelles shrank significantly and experienced membrane damage, which caused the loss of the initial shape of the cells (Li et al. 2015).

An interesting strategy was reported in order to control the PDT activity in cancer treatment. Li et al. (Li et al. 2014) incorporated pheophorbide a (Figure 2) in polymeric micelles based on poly(ethylene glycol)-b-poly(caprolactone) (PEGb-PCL), together with $\beta$-carotene a well-known ${ }^{1} \mathrm{O}_{2}$ scavenger. The aim of the authors was that the presence $\beta$-carotene in the micelles would minimize the PS phototoxicity during blood circulation, but it would be maintained after internalization of both components into separated intracellular compartments of the tumor cells. The efficiency of these carriers, at various concentrations and after irradiation with light at $1.7 \mathrm{~J} / \mathrm{cm}^{2}$, was tested against MCF7 cells (a human breast-cancer cell line) and HeLa cells and was compared with the one of free pheophorbide $a$. The studies showed that the physical co-incorporation of $\beta$-carotene and pheophorbide $a$ did not cause FRET-based quenching, but the presence of $\beta$-carotene in the micelles was found to inhibit significantly ${ }^{1} \mathrm{O}_{2}$ generation. As it was envisaged, the ${ }^{1} \mathrm{O}_{2}$ scavenging was inhibited when the pheophorbide $a$ and $\beta$-carotene were spatially isolated through the 


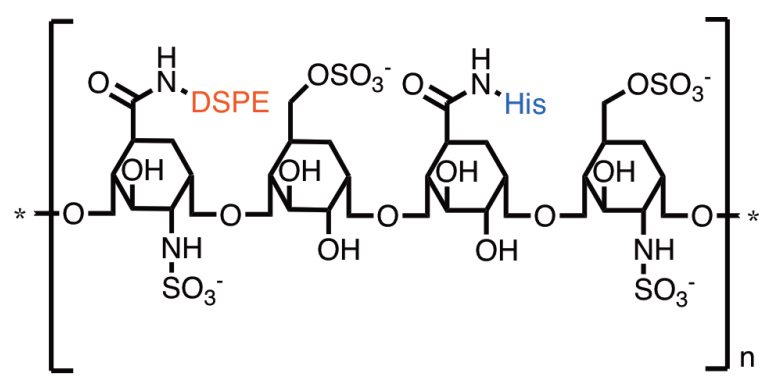

Figure 18 - Structure of a micelle composed of heparin, phospholipids and histidine.

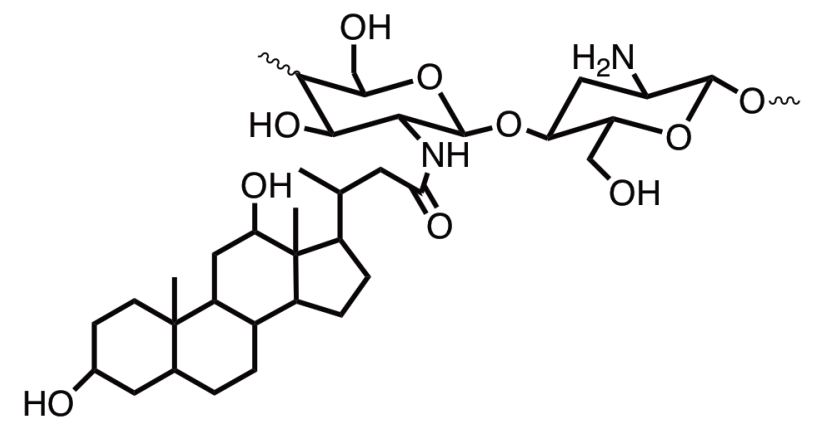

Figure 19 - Structure of an amphiphilic chitosan derivative conjugated with deoxycholic acid groups.

disintegration of the micelles and the internalized pheophorbide $a / \beta$-carotene micelles exhibited remarkable phototoxicity toward tumor cells MCF7 and HeLa cells (Li et al. 2014).

Another interesting contribution was reported by Dai et al. (Dai et al. 2016). The authors developed a ROS sensitive drug delivery system based on the self-assembly of an amphiphilic polymer of poly(propylene sulfide)-polyethylene glycol-serinefolic acid. The resulting micelles were loaded with the hydrophobic zinc(II) phthalocyanine (Figure 2) and the anti-cancer drug doxorubicin (DOX). The study showed that the physiological intracellular ROS and the ROS generated by the zinc(II) phthalocyanine under laser irradiation $\left(1 \mathrm{~W} / \mathrm{cm}^{2}\right)$, were able to promote the disassembly of micelles and the anti-tumor drug release. Additionally, the in vitro and in vivo evaluations in a human liver cancer cell line (HepG2) revealed that these ROS sensitive micelles could effectively target tumor tissue/cells to initiate cell apoptosis and suppress tumor growth with minimal toxic side effect. It was commented that the high concentration of ROS produced by the PS could also be responsible by the efficient killing of the tumor cells.

The same concept was reported in a previous study by Kim et al. (Kim et al. 2016). After the incorporation of DOX in the copolymer poly(ethylene glycol)-block-poly(propylene sulfide) covalently linked to chlorin $e_{6}$ (PPS-PEG$\mathrm{Ce}_{6}$ ) (Figure 20a) the authors demonstrated that chlorin $\mathrm{e}_{6}$ upon spatiotemporal irradiation, was able to generate $\mathrm{ROS}$ ( such as ${ }^{1} \mathrm{O}_{2}$ and adjacent free radicals), and consequently to induce DOXrelease triggering and endo/lysosomal rupture. The potentiality of the therapeutic efficacy of this synergistic approach was evaluated in vitro using human colon cancer (HCT-116) cells and in vivo using BALB/c mice inoculated with K-1735 cells.

Also taking in mind this dual-modality system for cancer treatment, Chen et al. (Chen et al. 2016a) encapsulated the anti-cancer drug DOX and the meso-tetraphenylchlorin as the PS in a series of thermo- and $\mathrm{pH}$-responsive block copolymers, poly( $\varepsilon$-caprolactone $)-b$-poly $[N$ isopropylacrylamide-co- $N$-methacryloyl- $\beta$-alanine (PCL- $b$-p(NIPAAM-co- $\beta$ A)] (Figure 20b). The cytotoxicity study showed that PS-loaded micelle without light irradiation was non-toxic to HeLa cells. However, under light irradiation $(660 \mathrm{~nm}$, $30 \mathrm{~mW} / \mathrm{cm}^{2}$ ) for $6 \mathrm{~min}$, the micelles showed an improved therapeutic efficiency by generating ${ }^{1} \mathrm{O}_{2}$ accompanied with the release of DOX (Chen et al. 2016a).

Other recent publications using $\mathrm{PMs}$ as delivery carrier for PDT or for a combined therapy confirmed the high efficiency of this type of nanocarriers (Dehghankelishadi and Dorkoosh 2016, Pellosi et al. 2016a, b, 2017, Zhang et al. 2015). 
a.

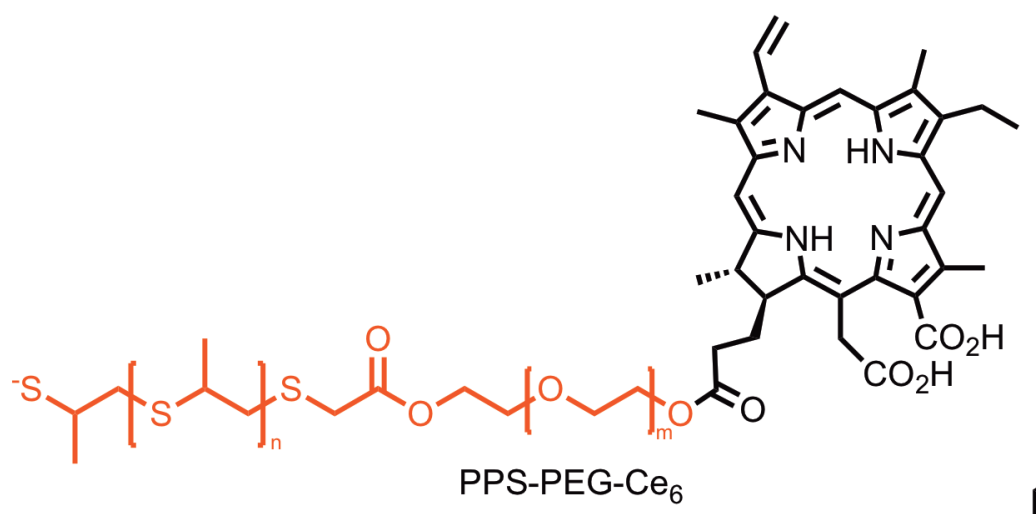

b.
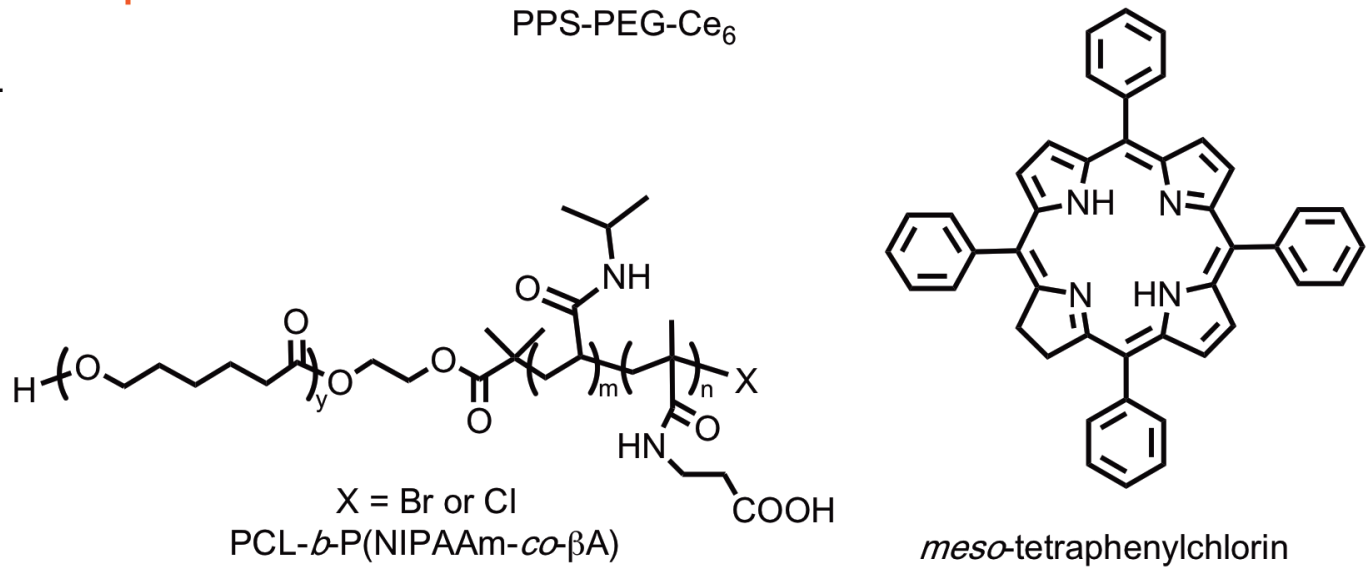

Figure 20 - Structures of a. chlorin $e_{6}$ conjugated with poly(ethylene glycol)-block-poly(propylene sulfide) copolymer, and b. poly( $\varepsilon$-caprolactone)- $b$-poly $[N$-isopropylacrylamide- $c o-N$-methacryloyl- $\beta$-alanine $]$ and mesotetraphenylchlorin.

\section{CONCLUSIONS}

PDT has emerged as one important therapeutic option in the treatment of cancer and other nononcological diseases. However, despite its benefits over current treatments, PDT is yet to gain general clinical acceptance. There are several technical drawbacks in the application of this therapy to a wide range of diseases. Firstly, currently FDA approved PSs for PDT mainly absorb in the visible spectral regions below $630 \mathrm{~nm}$, where light penetration into the skin is only a few millimeters, thus limiting PDT application to relatively superficial lesions. Secondly, it is difficulty to prepare pharmaceutical formulations that enable parenteral administration since most existing PSs are hydrophobic and simply aggregate under physiological conditions. Finally, the PS selectivity to diseased tissues is frequently not sufficiently high as required for clinical applications, exhibiting among other drawbacks, prolonged skin sensitization.

Therefore, the application of NPs in the field of PDT proposes resolutions to some of these difficulties and has great importance to the further development of this therapy. Although, much more research work is still required. Very few clinical studies have assessed the effect of the different delivery systems in terms of clinical efficiency. Beyond the laboratory Petri dish, this approach still needs responses such as appropriate dosage, delivery system and light exposure times that will maximize clinical effectiveness, while minimizing side effects.

\section{ACKNOWLEDGMENTS}

The authors acknowledge the University of Aveiro and FCT/MEC (Fundação para a Ciência e a 
Tecnologia, Ministério da Educação e da Ciência), through national founds and, where applicable, co-financed by the FEDER (European Fund for Regional Development) within the PT2020 Partnership Agreement, and Compete 2020 for the financial support to the QOPNA research project (FCT UID/QUI/00062/2013) and Institute for Biomedicine - iBiMED (UID/BIM/04501/2013). MQM thanks FCT for her doctoral grant (SFRH/ $\mathrm{BD} / 112317 / 2015)$.

\section{REFERENCES}

ADAMS ML, LAVASANIFAR A AND KWON GS. 2003. Amphiphilic Block Copolymers for drug delivery. J Pharm 92: 1343-1355.

AGOSTINIS P ET AL. 2011. Photodynamic therapy of cancer: An update. CA Cancer J Clin 61: 250-281.

AL-AHMADY Z, LOZANO N, MEI KC, AL-JAMAL WT AND KOSTARELOS K. 2016. Engineering thermosensitive liposome-nanoparticle hybrids loaded with doxorubicin for heat-triggered drug release. Int $\mathrm{J}$ Pharm 514: 133-141.

ALLÉMANN E, BRASSEUR N, BENREZZAK O, ROUSSEAU J, KUDREVICH SV, BOYLE RW, LEROUX JC, GURNY R AND VAN LIER JE. 1995. PegCoated Poly(Lactic Acid) Nanoparticles for the Delivery of Hexadecafluoro Zinc Phthalocyanine To Emt-6 Mouse Mammary-Tumors. J Pharm Pharmacol 47: 382-387.

ALLÉMANN E, BRASSEUR N, KUDREVICH SV, LA MADELEINE C AND VAN LIER JE. 1997. Photodynamic activities and biodistribution of fluorinated zinc phthalocyanine derivatives in the murine EMT-6 tumour model. Int J Cancer 72: 289-294.

ALLÉMANN E, ROUSSEAU J, BRASSEUR N, VUDREVICH SV, LEWIS K AND VAN LIER JE. 1996. Photodymamic therapy of tumours with hexadecafluoro zinc phthalocyanine formulated in peg-coated poly(lactic acid) nanoparticles. Int J Cancer 66: 821-824.

ALLISON RR, CUENCA RE, DOWNIE GH, CAMNITZ P, BRODISH B AND SIBATA CH. 2005. Clinical photodynamic therapy of head and neck cancers - A review of applications and outcomes. Photodiagnosis Photodyn Ther 2: 205-222.

ALLISON RR AND SIBATA CH. 2010. Oncologic photodynamic therapy photosensitizers: A clinical review. Photodiagnosis Photodyn Ther 7: 61-75.

ALMEIDA A, CUNHA A, FAUSTINO MAF, TOME AC AND NEVES MGPMS. 2011. Chapter 5 Porphyrins as antimicrobial photosensitizing agents. Photodynamic inactivation of microbial pathogens: Medical and environmental applications: The Royal Society of Chemistry, p. 83-160.

ALMEIDA J, TOMÉ JPC, NEVES MGPMS, TOMÉ AC, CAVALEIRO JAS, CUNHA Â, COSTA L, FAUSTINO MAF AND ALMEIDA A. 2014. Photodynamic inactivation of multidrug-resistant bacteria in hospital wastewaters: influence of residual antibiotics. Photochem Photobiol Sci 13: 626-633.

ALVES E, FAUSTINO MAF, NEVES MGPMS, CUNHA $\hat{A}$, NADAIS H AND ALMEIDA A. 2015. Potential applications of porphyrins in photodynamic inactivation beyond the medical scope. J Photochem Photobiol C Photochem Rev 22: 34-57.

ALVES E, FAUSTINO MAF, TOMÉ JPC, NEVES MGPMS, TOMÉ AC, CAVALEIRO JAS, CUNHA Â, GOMES NCM AND ALMEIDA A. 2011. Photodynamic antimicrobial chemotherapy in aquaculture: Photoinactivation studies of Vibrio fischeri. PLoS ONE 6: e20970.

AMINI SM, KHARRAZI S, HADIZADEH M, FATEH M AND SABER R. 2013. Effect of gold nanoparticles on photodynamic efficiency of 5-aminolevolenic acid photosensitiser in epidermal carcinoma cell line: an in vitro study. IET Nanobiotechnol 7: 151-156.

ATTIA ABE, ONG ZY, HEDRICK JL, LEE PP, EE PLR, HAMMOND PT AND YANG YY. 2011. Mixed micelles self-assembled from block copolymers for drug delivery. Curr Opin Colloid Interface Sci 16: 182-194.

BACHOR R, REICH E, MILLER K, RÜCK A AND HAUTMANN R. 1995. Photodynamic efficiency of liposome-administered tetramethyl hematoporphyrin in two human bladder cancer cell lines. Urol Res 23: 151156.

BADER H, KINGSDORF H AND SCHMIDT B. 1984. Water soluble polymers in medicine. Angew Makromol Chem 123: 457-485

BANERJEE R. 2001. Liposomes: Applications in Medicine. J Biomater Appl 16: 3-21.

BIJU V. 2014. Chemical modifications and bioconjugate reactions of nanomaterials for sensing, imaging, drug delivery and therapy. Chem Soc Rev 43: 744-764.

BIOLO R, JORI G, SONCIN M, RIHTER B, KENNEY ME AND RODGERS MA. 1996. Effect of photosensitizer delivery system and irradiation parameters on the efficiency of photodynamic therapy of B16 pigmented melanoma in mice. Photochem Photobiol 63: 224-228.

BIRRENBACH G AND SPEISER P. 1976. Polymerized micelles and their use as adjuvants in immunology. J Pharm Sci 65: 1763-1766.

BONNETT R. 1995. Photosensitizers of the porphyrin and phthalocyanine series for photodynamic therapy. Chem Soc Rev 24: 19-33.

BONNETT R, KRYSTEVA MA, LALOV IG AND ARTARSKY SV. 2006. Water disinfection using 
photosensitizers immobilized on chitosan. Water Res 40: 1269-1275.

BRASSEUR N, OUELLET R, LA MADELEINE C AND VAN LIER JE. 1999. Water-soluble aluminium phthalocyaninepolymer conjugates for PDT: photodynamic activities and pharmacokinetics in tumour-bearing mice. Br J Cancer 80: 1533-1541.

CALIXTO GM, BERNEGOSSI J, DE FREITAS LM, FONTANA CR AND CHORILLI M. 2016. Nanotechnology-based drug delivery systems for photodynamic therapy of cancer: A review. Molecules 21: 342.

CAMERIN M, MAGARAGGIA M, SONCIN M, JORI G, MORENO M, CHAMBRIER I, COOK MJANDRUSSELL DA. 2010. The in vivo efficacy of phthalocyaninenanoparticle conjugates for the photodynamic therapy of amelanotic melanoma. Eur J Cancer 46: 1910-1918.

CARVALHO CMB ET AL. 2007. Photoinactivation of bacteria in wastewater by porphyrins: Bacterial $\beta$-galactosidase activity and leucine-uptake as methods to monitor the process. J Photochem Photobiol B Biol 88: 112-118.

CASTANO AP, DEMIDOVA TN AND HAMBLIN MR. 2004. Mechanisms in photodynamic therapy: Part one Photosensitizers, photochemistry and cellular localization. Photodiagnosis Photodyn Ther 1: 279-293.

CASTILHO ML, VIEIRA LS, CAMPOS APC, ACHETE CA, CARDOSO MAG AND RANIERO L. 2015. The efficiency analysis of gold nanoprobes by FT-IR spectroscopy applied to the non-cross-linking colorimetric detection of Paracoccidioides brasiliensis, Sens Actuators B Chem 215: 258-265.

CHATTERJEE DK, FONG LS AND ZHANG Y. 2008. Nanoparticles in photodynamic therapy: An emerging paradigm. Adv Drug Deliv Rev 60: 1627-1637.

CHEN B, POGUE BW AND HASAN T. 2005. Liposomal delivery of photosensitising agents. Expert Opin Drug Deliv 2: 477-487.

CHEN CY, WANG YC AND HUNG CC. 2016a. In vitro dual-modality chemo-photodynamic therapy via stimulitriggered polymeric micelles. React Funct Polym 98: 5664.

CHEN WH, LUO GF, QIU WX, LEI Q, LIU LH, WANG SB AND ZHANG XZ. 2016b. Mesoporous silica-based versatile theranostic nanoplatform constructed by layerby-layer assembly for excellent photodynamic/chemo therapy. Biomaterials 117: 54-65.

CHENG Y, SAMIA AC, MEYERS JD, PANAGOPOULOS I, FEI B AND BURDA C. 2008. Highly efficient drug delivery with gold nanoparticle vectors for in vivo photodynamic therapy of cancer. J Am Chem Soc 130: 10643-10647.
CHILAKAMARTHI U AND GIRIBABU L. 2017. Photodynamic Therapy: Past, present and future. Chem Rec 17: 775-802.

CHOUIKRAT R, SEVE A, VANDERESSE R, BENACHOUR H, BARBERI-HEYOB M, RICHETER S, RAEHM L, DURAND JO, VERELST M AND FROCHOT C. 2012. Non polymeric nanoparticles for photodynamic therapy applications: Recent developments. Curr Med Chem 19: 781-792.

CORDEIRO RM, MIOTTO R AND BAPTISTA MS. 2012. Photodynamic efficiency of cationic meso-porphyrins at lipid bilayers: insights from molecular dynamics simulations. J Phys Chem B 116: 14618-14627.

COSTA L, CARVALHO CMB, FAUSTINO MAF, NEVES MGPMS, TOMÉ JPC, TOMÉ AC, CAVALEIRO JAS, CUNHA Â AND ALMEIDA A. 2010. Sewage bacteriophage inactivation by cationic porphyrins: influence of light parameters. Photochem Photobiol Sci 9: 1126-1133.

COSTA L, TOMÉ JPC, NEVES MGPMS, TOMÉ AC, CAVALEIRO JAS, FAUSTINO MAF, CUNHA Â, GOMES NCM AND ALMEIDA A. 2011. Evaluation of resistance development and viability recovery by a nonenveloped virus after repeated cycles of aPDT. Antiviral Res 91: 278-282.

COULEAUD P, MOROSINI V, FROCHOT C, RICHETER S, RAEHM L AND DURAND JO. 2010. Silica-based nanoparticles for photodynamic therapy applications. Nanoscale 2: 1083-1095.

COUVREUR P, GRISLAIN L, LENAERTS V, BRASSEUR F, GIOT P AND BIORNACKI A. 1986. Biodegradable polymeric nanoparticles as drug carrier for antitumor agents. In: Giot P and Couvreur P (Eds), Polymeric Nanoparticles Microspheres, Boca Raton: CRC Press, p. 27-93.

COZZANI I, JORI G, BERTOLONI G, MILANESI C, CARLINI P, SICURO T AND RUSCHI A. 1985. Efficient photosensitization of malignant human cells in vitro by liposome-bound porphyrins. Chem Biol Interact 53: 131143.

CROY SR AND KWON GS. 2006. Polymeric micelles for drug delivery. Curr Pharm Des 12: 4669-4684.

DAI L ET AL. 2016. Photosensitizer enhanced disassembly of amphiphilic micelle for ROS-response targeted tumor therapy in vivo. Biomaterials 104: 1-17.

DAMOISEAU X, SCHUITMAKER HJ, LAGERBERG JWM AND HOEBEKE M. 2001. Increase of the photosensitizing efficiency of the bacteriochlorin $a$ by liposome-incorporation. J Photochem Photobiol B Biol 60: $50-60$.

DARWENT JR, MCCUBBIN I AND PHILLIPS D. 1982. Excited singlet and triplet state electron-transfer reactions 
of aluminium (III) sulphonated phthalocyanie. J Chem Soc, Faraday Trans 2 78: 347-357.

DEBELE TA, MEKURIA SL AND TSAI HC. 2017. A pHsensitive micelle composed of heparin, phospholipids, and histidine as the carrier of photosensitizers: Application to enhance photodynamic therapy of cancer. Int J Biol Macromol 98: 125-138.

DECKER C, FAHR A, KUNTSCHE J AND MAY S. 2012. Selective partitioning of cholesterol and a model drug into liposomes of varying size. Chem Phys Lipids 165: 520529.

DEHGHANKELISHADI P AND DORKOOSH F. 2016. Pluronic based nano-delivery systems; Prospective warrior in war against cancer. Nanomed Res J 1: 1-7.

DENG H, LI T, XIE J, HUANG N, GU Y AND ZHAO J. 2013a. Synthesis and bio-evaluation of novel hypocrellin derivatives: Potential photosensitizers for photodynamic therapy of age-related macular degeneration. Dye Pigment 99: 930-939.

DENG X, XIONG L, LIN L, XIONG G AND MIAO X. 2013b. Photosan-II loaded hollow silica nanoparticles: Preparation and its effect in killing for QBC939 cells. Photodiagnosis Photodyn Ther 10: 460-469.

DEROSA MC AND CRUTCHLEY RJ. 2002. Photosensitized singlet oxygen and its applications. Coord Chem Rev 233234: 351-371.

DERYCKE ASL AND DE WITTE PAM. 2004. Liposomes for photodynamic therapy. Adv Drug Deliv Rev 56: 17-30.

DOLMANS DEJGJ, FUKUMURA D AND JAIN RK. 2003. Photodynamic therapy for cancer. Nat Rev Cancer 3: 380387.

DOS SANTOS CA, SECKLER MM, INGLE AP, GUPTA I, GALDIERO S, GALDIERO M, GADE A AND RAI M. 2014. Silver nanoparticles: therapeutical uses, toxicity, and safety issues. J Pharm Sci 103: 1931-1944.

DRAGICEVIC-CURIC N, WINTER S, STUPAR M, MILIC J, KRAJIŠNIK D, GITTER B AND FAHR A. 2009. Temoporfin-loaded liposomal gels: Viscoelastic properties and in vitro skin penetration. Int J Pharm 373: 77-84.

DRUMMOND DC, MEYER O, HONG K, KIRPOTIN DB AND PAPAHADJOPOULOS D. 1999. Optimizing liposomes for delivery of chemotherapeutic agents to solid tumors. Pharmacol Rev 51: 691-743.

ERZINGER GS, WOHLLEBE S, VOLLRATH F, SOUZA SC, RICHTER P, LEBERT M AND HÄDER DP. 2011. Optimizing conditions for the use of chlorophyll derivatives for photodynamic control of parasites in aquatic ecosystems. Parasitol Res 109: 781-786.

FAUSTINO MAF, NEVES MGPMS, CAVALEIRO JAS, NEUMANN M, BRAUER HD AND JORI G. 2000. Part 2. meso-tetraphenylporphyrin dimer derivatives as potential photosensitizers in photodynamic therapy. Photochem Photobiol 72: 217-225.
FAUSTINO MAF, NEVES MGPMS, VICENTE MGH, CAVALEIRO JAS, NEUMANN M, BRAUER HD AND JORI G. 1997. Meso-tetraphenylporphyrin dimer derivative as a potential photosensitizer in photodynamic therapy. Photochem Photobiol 66: 405-412.

FEHR MK, WALT H, WYSS P, BERNS MW AND TADIR Y. 2000. PEG- $m$-THPC - mediated photodynamic effects on normal rat tissues. Photochem Photobiol 72: 696-700.

FEOFANOV A, GRICHINE A, KARMAKOVA T, PLJUTINSKAYA A, LEBEDEVA V, FILYASOVA A, YAKUBOVSKAYA R, MIRONOV A, EGRETCHARLIER M AND VIGNY P. 2002. Near-infrared photosensitizer based on a cycloimide derivative of chlorin p6: 13,15-N-(3'-hydroxypropyl)cycloimide chlorin p6. Photochem Photobiol 75: 633-643.

FERREIRA DC, MONTEIRO CS, CHAVES CR, SÁFAR GAM, MOREIRARL, PINHEIRO MVB, MARTINS DCS, LADEIRA LO AND KRAMBROCK K. 2016. Hybrid systems based on gold nanostructures and porphyrins as promising photosensitizers for photodynamic therapy. Colloids Surf B Biointerfaces 150: 297-307.

FLORENCE AT AND HUSSAIN N. 2001. Transcytosis of nanoparticle and dendrimer delivery systems: evolving vistas. Adv Drug Deliv Rev 50: S69-S89.

GIANOTTI E, ESTEVÃO BM, MILETTO I, TONELLO S, RENÒ F AND MARCHESE L. 2016. Verteporfin based silica nanoplatform for photodynamic therapy. Chem Sel Commun 2: 127-131.

GUPTA A, AVCI P, SADASIVAM M, CHANDRAN R, PARIZOTTO N, VECCHIO D, DE MELO WCMA, DAI T, CHIANG LY AND HAMBLIN MR. 2013. Shining light on nanotechnology to help repair and regeneration. Biotechnol Adv 31: 607-631.

HAMBLIN MR, MILLER JL, RIZVI I, LOEW HG AND HASAN T. 2003. Pegylation of charged polymerphotosensitiser conjugates: effects on photodynamic efficacy. Br J Cancer 89: 937-943.

HAMBLIN MR, MILLER JL, RIZVI I, ORTEL B, MAYTIN EV AND HASAN T. 2001. Pegylation of a chlorin e6 polymer conjugate increases tumor targeting of photosensitizer. Cancer Res 61: 7155-7162.

HAMBLIN MR AND MROZ P. 2008. Advances in Photodynamic Therapy: Basic, Translational, and Clinical. London: Artech House.

HAMBLIN MR, RAJADHYAKSHA M, MOMMA T, SOUKOS NS AND HASAN T. 1999. In vivo fluorescence imaging of the transport of charged chlorin e 6 conjugates in a rat orthotopic prostate tumour. Br J Cancer 81: 261268.

HU Y, CHEN R, ZHANG L, GAO J, WU W AND JIANG X. 2011. Chemiluminescent nanomicelles for imaging hydrogen peroxide and self-therapy in photodynamic therapy. J Biomed Biotechnol 2011: 1-9. 
HUANG DM ET AL. 2005. Highly efficient cellular labeling of mesoporous nanoparticles in human mesenchymal stem cells: implication for stem cell tracking. FASEB J 19: 2014-2016.

HUANG H AND HASAN T. 2014. The "nano" world in photodynamic therapy. Austin J Nanomed Nanotechnol 2: $2-5$.

HUANG L, CHEN TC AND LIN FH. 2013. Luminol as in situ light source in meso-tetraphenylporphyrin-mediated photodynamic therapy. Curr Med Chem 20: 1195-1202.

IGARASHI A, KONNO H, TANAKA T, NAKAMURA S, SADZUKA Y, HIRANO T AND FUJISE Y. 2003. Liposomal photofrin enhances therapeutic efficacy of photodynamic therapy against the human gastric cancer. Toxicol Lett 145: 133-141.

IRANIFAM M. 2014. Analytical applications of chemiluminescence methods for cancer detection and therapy. Trends Anal Chem 59: 156-183.

JAIN RK. 2001. Delivery of molecular medicine to solid tumors: Lessons from in vivo imaging of gene expression and function. J Control Release 74: 7-25.

JANA S AND PAL T. 2007. Synthesis, characterization and catalytic application of silver nanoshell coated functionalized polystyrene beads. J Nanosci Nanotechnol 7: 2151-2156.

JEŽEK P, NEKVASIL M, ŠKOBISOVÁ E, URBÁNKOVÁ E, JIRSA M, ZADINOVÁ M, POUČKOVÁ P AND KLEPÁCEK I. 2003. Experimental photodynamic therapy with meso-tetrakisphenylporphyrin (TPP) in liposomes leads to disintegration of human amelanotic melanoma implanted to nude mice. Int J Cancer 103: 693-702.

JIANG F, LILGE L, GRENIER J, LI Y, WILSON MD AND CHOPP M. 1998. Photodynamic therapy of U87 human glioma in nude rat using liposome-delivery photofrin. Lasers Surg Med 22: 74-80.

JIANG F, LILGE L, LOGIE B, LI Y AND CHOPP M. 1997. Photodynamic therapy of 9L gliosarcoma with liposomedelivered photofrin. Photochem Photobiol 65: 701-706.

JORI G, TOMIO L, REDDI E, ROSSI E, CORTI L, ZORAT PL AND CALZAVARA F. 1983. Preferential delivery of liposome-incorporated porphyrins to neoplastic cells in tumour-bearing rats. Br J Cancer 48: 307-309.

JUARRANZ Á, JAÉN P, SANZ-RODRÍGUEZ F, CUEVAS J AND GONZÁLEZ S. 2008. Photodynamic therapy of cancer Basic principles and applications. Clin Transl Oncol 10: 148-154.

KADISH KM, GUILARD RAND SMITH KM. 2012. Medical Aspects of Porphyrins. In: The porphyrin Handbook, New York: Elsevier, 347 p.

KAHRAMAN E, KARAGOZ A, DINCER S AND OZSOY Y. 2015. Polyethylenimine modified and non-modified polymeric micelles used for nasal administration of carvedilol. J Biomed Nanotechnol 11: 890-899.
KAKIZAWA Y, HARADA A AND KATAOKA K. 1999. Environment-sensitive stabilization of core-shell structured polyion complex micelle by reversible crosslinking of the core through disulfide bond. J Am Chem Soc 121: 11246-11248.

KAKIZAWA Y AND KATAOKA K. 2002. Block copolymer micelles for delivery of gene and related compounds. Adv Drug Deliv Rev 54: 203-222.

KATAYAMA Y, SONODA T AND MAEDA M. 2001. A polymer micelle responding to the protein kinase a signal. Macromolecules 34: 8569-8573.

KEPCZYŃSKI M, PANDIAN RP, SMITH KM AND EHRENBERG B. 2002. Do liposome-binding constants of porphyrins correlate with their measured and predicted partitioning between octanol and water? Photochem Photobiol 76: 127-134.

KIM K, LEE CS AND NA K. 2016. Light-controlled reactive oxygen species (ROS)-producible polymeric micelles with simultaneous drug-release triggering and endo/lysosomal escape. Chem Commun 52: 2839-2842.

KONAN YN, GURNY R AND ALLÉMANN E. 2002. State of the art in the delivery of photosensitizers for photodynamic therapy. J Photochem Photobiol B Biol 66: 89-106.

KONAN YN, CERNY R, FAVET J, BERTON M, GURNY R AND ALLÉMANN E. 2003. Preparation and characterization of sterile sub-200 $\mathrm{nm}$ meso-tetra(4hydroxylphenyl)porphyrin-loaded nanoparticles for photodynamic therapy. Eur J Pharm Biopharm 55: 115124.

KRASNOVSKY AA, LOPEZ J, CHENG P, LIDDELL PA, BLANKENSHIP RE, MOORE TA AND GUST D. 1994. Generation and quenching of singlet molecular oxygen by aggregated bacteriochlorophyll $\mathrm{d}$ in model systems and chlorosomes. Photosynth Res 40: 191-198.

KRUKIEWICZ K AND ZAK JK. 2016. Biomaterial-based regional chemotherapy: Local anticancer drug delivery to enhance chemotherapy and minimize its side-effects. Mater Sci Eng C Mater Biol Appl 62: 927-942.

KUMAR N, RAVIKUMAR MNV AND DOMB AJ. 2001. Biodegradable block copolymers. Adv Drug Deliv Rev 53: 23-44.

KWON GS. 2003. Polymeric micelles for delivery of poorly water-soluble compounds. Crit Rev Ther Drug Carrier Syst 20: 357-403.

KWON G, SUWA S, YOKOYAMA M, OKANO T, SAKURAI Y AND KATAOKA K. 1994. Enhanced tumor accumulation and prolonged circulation times of micelleforming poly (ethylene oxide-aspartate) block copolymeradriamycin conjugates. J Control Release 29: 17-23.

LAMCH Ł, BAZYLIŃSKA U, KULBACKA J, PIETKIEWICZ J, BIEŻUŃSKA-KUSIAK K AND WILK KA. 2014. Polymeric micelles for enhanced Photofrin II ${ }^{\circledR}$ delivery, cytotoxicity and pro-apoptotic activity in human 
breast and ovarian cancer cells. Photodiagnosis Photodyn Ther 11: 570-585.

LAMCH Ł, KULBACKA J, PIETKIEWICZ J, ROSSOWSKA J, DUBIŃSKA-MAGIERA M, CHOROMAŃSKA A AND WILK KA. 2016. Preparation and characterization of new zinc(II) phthalocyanine - Containing poly(1lactide)-b-poly(ethylene glycol) copolymer micelles for photodynamic therapy. J Photochem Photobiol B Biol 160: 185-197.

LAPTEV R, NISNEVITCH M, SIBONI G, MALIK Z AND FIRER MA. 2006. Intracellular chemiluminescence activates targeted photodynamic destruction of leukaemic cells. Br J Cancer 95: 189-196.

LI H, YU Z, WANG S, LONG X, ZHANG LM, ZHU Z AND YANG L. 2015. Photosensitizer-encapsulated amphiphilic chitosan derivative micelles: Photoactivity and enhancement of phototoxicity against human pancreatic cancer cells. J Photochem Photobiol B Biol 142: 212-219.

LI L, CHO H, YOON KH, KANG HC AND HUH KM. 2014. Antioxidant-photosensitizer dual-loaded polymeric micelles with controllable production of reactive oxygen species. Int J Pharm 471: 339-348.

LI SD AND HUANG L. 2008. Pharmacokinetics and biodistribution of nanoparticles. Mol Pharm 5: 496-504.

LIN R, ZHOU L, LIN Y, WANG A, ZHOU JH AND WEI SH. 2011. Property study of a new silica nanoparticle delivery system of hydrophobic phthalocyanine using spectroscopic method. Spectroscopy 26: 179-185.

LIN YS, WU SH, HUNG Y, CHOU YH, CHANG C, LIN ML, TSAI CP AND MOU CY. 2006. Multifunctional composite nanoparticles: Magnetic, luminescent, and mesoporous. Chem Mater 18: 5170-5172.

LIU Z AND YANG C. 2016. A mathematical model of cancer treatment by radiotherapy followed by chemotherapy. Math Comput Simul 124: 1-15.

LOVČINSKÝ M, BORECKÝ J, KUBÁT P AND JEŽEK P. 1999. Meso-tetraphenylporphyrin in liposomes as a suitable photosenzitizer for photodynamic therapy of tumors. Gen Physiol Biophys 18: 107-118.

LU J, LIONG M, ZINK JI AND TAMANOI F. 2007. Mesoporous silica nanoparticles as a delivery system for hydrophobic anticancer drugs. Small 3: 1341-1346.

LUCKY SS, SOO KC AND ZHANG Y. 2015. Nanoparticles in photodynamic therapy. Chem Rev 115: 1990-2042.

LUO D, CARTER KA, RAZI A, GENG J, SHAO S, GIRALDO D, SUNAR U, ORTEGA J AND LOVELL JF. 2016. Doxorubicin encapsulated in stealth liposomes conferred with light-triggered drug release. Biomaterials 75: 193-202.

MAEDA H. 2001. The enhanced permeability and retention (EPR) effect in tumor vasculature: the key role of tumorselective macromolecular drug targeting. Adv Enzyme Regul 41: 189-207.
MAEDA H, WU J, SAWA T, MATSUMURA Y AND HORI K. 2000. Tumor vascular permeability and the EPR effect in macromolecular therapeutics: a review. J Control Release 65: 271-284.

MAKKY A, MICHEL JP, MAILLARD P AND ROSILIO V. 2011. Biomimetic liposomes and planar supported bilayers for the assessment of glycodendrimeric porphyrins interaction with an immobilized lectin. Biochim Biophys Acta, Biomembr 1808: 656-666.

MANAGA M, BRITTON J, PRINSLOO E AND NYOKONG T. 2016. Effects of pluronic silica nanoparticles on the photophysical and photodynamic therapy behavior of triphenyl-p-phenoxy benzoic acid metalloporphyrins. J Coord Chem 69: 3491-3506.

MARAMBIO-JONES C AND HOEK E. 2010. A review of the antibacterial effects of silver nanomaterials and potential implications for human health and the environment. J Nanoparticle Res 12: 1531-1551.

MASTER A, LIVINGSTON M AND SEN GUPTA A. 2013. Photodynamic nanomedicine in the treatment of solid tumors: Perspectives and challenges. J Control Release 28: 88-102.

MEDINA OP, ZHU Y AND KAIREMO K. 2004. Targeted liposomal drug delivery in cancer. Curr Pharm Des 10: 2981-2989.

MESQUITA MQ ET AL. 2014. Pyrrolidine-fused chlorin photosensitizer immobilized on solid supports for the photoinactivation of Gram negative bacteria. Dye Pigment 110: 123-133.

MILLER KD, SIEGEL RL, LIN CC, MARIOTTO AB, KRAMER JL, ROWLAND JH, STEIN KD, ALTERI R AND JEMAL A. 2016. Cancer treatment and survivorship statistics, 2016. CA Cancer J Clin 66: 271-289.

MORETTON MA, HOCHT C, TAIRA C AND SOSNIK A. 2014. Rifampicin-loaded "flower-like" polymeric micelles for enhanced oral bioavailability in an extemporaneous liquid fixed-dose combination with isoniazid. Nanomedicine 9: 1635-1650.

NAM G, RANGASAMY S, JU H, SAMSON AAS AND SONG JM. 2017. Cell death mechanistic study of photodynamic therapy against breast cancer cells utilizing liposomal delivery of 5,10,15,20-tetrakis(benzo[b] thiophene) porphyrin. J Photochem Photobiol B Biol 166: 116-125.

NAMIKI Y, NAMIKI T, DATE M, YANAGIHARA K, YASHIRO M AND TAKAHASHI H. 2004. Enhanced photodynamic antitumor effect on gastric cancer by a novel photosensitive stealth liposome. Pharmacol Res 50: 65-76.

NAWALANY K, RUSIN A, KĘPCZYŃSKI M, MIKHAILOV A, KRAMER-MAREK G, ŚNIETURA M, POŁTOWICZ J, KRAWCZYK Z AND NOWAKOWSKA M. 2009. Comparison of photodynamic efficacy of tetraarylporphyrin 
pegylated or encapsulated in liposomes: In vitro studies. J Photochem Photobiol B Biol 97: 8-17.

NERADOVIC D, VAN NOSTRUM CF AND HENNINK WE. 2001. Thermoresponsive polymeric micelles with controlled instability based on hydrolytically sensitive $\mathrm{N}$-isopropylacrylamide copolymers. Macromolecules 34: 7589-7591.

NOSAKA Y AND NOSAKA AY. 2017. Generation and Detection of Reactive Oxygen Species in Photocatalysis. Chem Rev 117: 11302-11336.

OGAWARA KI AND HIGAKI K. 2017. Nanoparticlebased photodynamic therapy: Current status and future application to improve outcomes of cancer treatment. Chem Pharm Bull 65: 637-641.

OHULCHANSKYY TY, ROY I, GOSWAMI LN, CHEN Y, BERGEY EJ, PANDEY RK, OSEROFF AR AND PRASAD PN. 2007. Organically modified silica nanoparticles with covalently incorporated photosensitizer for photodynamic therapy of cancer. Nano Lett 7: 28352842.

OLUWOLE DO AND NYOKONG T. 2017. Photophysicochemical behaviour of metallophthalocyanines when doped onto silica nanoparticles. Dye Pigment 136: 262272.

OO MKK, YANG Y, HU Y, GOMEZ M, DU H AND HONGJUN W. 2012. Gold nanoparticle-enhanced and size-dependent generation of reactive oxygen species from Protoporphyrin IX. ACS Nano 6: 1939-1947.

ORMOND AB AND FREEMAN HS. 2013. Dye sensitizers for photodynamic therapy. Materials 6: 817-840.

PASPARAKIS G. 2013. Light-induced generation of singlet oxygen by naked gold nanoparticles and its implications to cancer cell phototherapy. Small 9: 4130-4134.

PELLOSI DS, CALORI IR, DE PAULA LB, HIOKA N, QUAGLIA F AND TEDESCO AC. 2017. Multifunctional theranostic Pluronic mixed micelles improve targeted photoactivity of Verteporfin in cancer cells. Mater Sci Eng C 71: 1-9.

PELLOSIDS, MORET F, FRAIXA, MARINO N, MAIOLINO S, GAIO E, HIOKA N, REDDI E, SORTINO S, QUAGLIA F. 2016a. Pluronic $\AA$ P123/F127 mixed micelles delivering sorafenib and its combination with verteporfin in cancer cells. Int J Nanomedicine 11: 4479-4494.

PELLOSI DS, TESSARO AL, MORET F, GAIO E, REDDI E, CAETANO W, QUAGLIA F AND HIOKA N. 2016b. Pluronic ${ }^{\circledR}$ mixed micelles as efficient nanocarriers for benzoporphyrin derivatives applied to photodynamic therapy in cancer cells. J Photochem Photobiol A Chem 314: 143-154.

PENG J, ZHAO L, ZHU X, SUN Y, FENG W, GAO Y, WANG L AND LI F. 2013. Hollow silica nanoparticles loaded with hydrophobic phthalocyanine for near-infrared photodynamic and photothermal combination therapy. Biomaterials 34: 7905-7912.

PENON O, MARÍN MJ, RUSSELL DA AND PÉREZGARCÍA L. 2017. Water soluble, multifunctional antibodyporphyrin gold nanoparticles for targeted photodynamic therapy J Colloid Interface Sci 496: 100-110.

PIAO Y, BURNS A, KIM J, WIESNER U AND HYEON T. 2008. Designed fabrication of silica-based nanostructured particle systems for nanomedicine applications. Adv Funct Mater 18: 3745-3758.

POLO L, BIANCO G, REDDI EAND JORI G. 1995. The effect of different liposomal formulations on the interaction of $\mathrm{Zn}(\mathrm{II})$-phthalocyanine with isolated low and high density lipoproteins. Int J Biochem Cell Biol 27: 1249-1255.

POPAT A, HARTONO SB, STAHR F, LIU J, QIAO SZ AND QUING MAX LU G. 2011. Mesoporous silica nanoparticles for bioadsorption, enzyme immobilisation, and delivery carriers. Nanoscale 3: 2801-2818.

POSTIGO F, MORA M, DE MADARIAGA MA, NONELL S AND SAGRISTÁ ML. 2004. Incorporation of hydrophobic porphyrins into liposomes: characterization and structural requirements. Int J Pharm 278: 239-254.

PY-DANIEL KR, NAMBAN JS, DE ANDRADE LR, DE SOUZA PEN, PATERNO LG, AZEVEDO RB AND SOLER MAG. 2016. Highly efficient photodynamic therapy colloidal system based on chloroaluminum phthalocyanine/pluronic micelles. Eur J Pharm Biopharm 103: 23-31.

RIESS G. 2003. Micellization of block copolymers. Prog Polym Sci 28: 1107-1170.

SAINI R, LEE NV, LIU KYP AND POH CF. 2016. Prospects in the application of photodynamic therapy in oral cancer and premalignant lesions. Cancers 8: 83 .

SALVATI A, RISTORI S, OBERDISSE J, SPALLA O, RICCIARDI G, PIETRANGELI D, GIUSTINI M AND MARTINI G. 2007. Small angle scattering and zeta potential of liposomes loaded with octa(carboranyl) porphyrazine. J Phys Chem B 111: 10357-10364.

SANVICENS N AND MARCO MP. 2008. Multifunctional nanoparticles - properties and prospects for their use in human medicine.Trends Biotechnol 26: 425-433.

SHERWANI MA, TUFAIL S, KHAN AA AND OWAIS M. 2015. Gold nanoparticle-photosensitizer conjugate based photodynamic inactivation of biofilm producing cells: potential for treatment of $C$. albicans infection in BALB/c mice. PLoS ONE 10: e0131684.

SHI W, SAHOO Y AND SWIHART MT. 2004. Gold nanoparticles surface-terminated with bifunctional ligands. Colloids Surfaces A Physicochem Eng Asp 246: 109-113.

SIEGEL RL, MILLER KD AND JEMAL A. 2016. Cancer statistics. CA Cancer J Clin 66: 7-30.

SILVA JN ET AL. 2006. Enhancement of the photodynamic activity of tri-cationic porphyrins towards proliferating 
keratinocytes by conjugation to poly-S-lysine. Photochem Photobiol Sci 5: 126-133.

SILVA JN ET AL. 2010. Chain-dependent photocytotoxicity of tricationic porphyrin conjugates and related mechanisms of cell death in proliferating human skin keratinocytes. Biochem Pharmacol 80: 1373-1385.

SIMON VETAL. 2010. Pp IX silica nanoparticles demonstrate differential interactions with in vitro tumor cell lines and in vivo mouse models of human cancers. Photochem Photobiol 86: 213-222.

SNEIDER A, JADIA R, PIEL B, VANDYKE D, TSIROS C AND RAI P. 2017. Engineering remotely triggered liposomes to target triple negative breast cancer. Oncomedicine 2: 1-13.

SOUKOS NS, HAMBLIN MR AND HASANT T. 1997. The effect of charge on cellular uptake and phototoxicity of polylysine chlorin e6 conjugates. Photochem Photobiol 65: 723-729.

SPIKES JD. 1983. A preliminary comparison of the photosensitizing properties of porphyrins in aqueous solution and liposomal systems. Adv Exp Med Biol 160: 181-192.

SPRING BQ, RIZVI I, XU N AND HASAN T. 2015. The role of photodynamic therapy in overcoming cancer drug resistance. Photochem Photobiol Sci 14: 1476-1491.

STALLIVIERI A, BAROS F, ARNOUX P, VANDERESSE R, BARBERI-HEYOB M AND FROCHOT C. 2016. Production of Singlet Oxygen by Nanoparticle-Bound Photosensitizers. In: Nonell S and Flors C (Eds), Singlet Oxygen: Applications in Biosciences and Nanoscience, Cambrige: The Royal Society of Chemistry, UK, p. 209223.

STEVENS PJ, SEKIDO M AND LEE RJ. 2004. Synthesis and evaluation of a hematoporphyrin derivative in a folate receptor-targeted solid-lipid nanoparticle formulation. Anticancer Res 24: 161-165.

STUBBE CE AND VALERO M. 2013. Complementary strategies for the management of radiation therapy side effects. J Adv Pr Oncol 4: 219-231.

SUN CC, BODURKA DC, WEAVER CB, RASU R, WOLF JK, BEVERS MW, SMITH JA, WHARTON JT AND RUBENSTEIN EB. 2005. Rankings and symptom assessments of side effects from chemotherapy: Insights from experienced patients with ovarian cancer. Support Care Cancer 13: 219-227.

TADA DB AND BAPTISTA MS. 2015. Photosensitizing nanoparticles and the modulation of ROS generation. Front Chem 3: 33.

TANG LAND CHENG J. 2013. Nonporous silica nanoparticles for nanomedicine application. Nano Today 8: 290-312.

TANG W, XU H, KOPELMAN RAND PHILBERT MA. 2007. Photodynamic characterization and in vitro application of methylene blue-containing nanoparticle platforms. Photochem Photobiol 81: 242-249.

TAO X, YANG YJ, LIU S, ZHENG YZ, FU J AND CHEN JF. 2013. Poly(amidoamine) dendrimer-grafted porous hollow silica nanoparticles for enhanced intracellular photodynamic therapy. Acta Biomater 9: 6431-6438.

TAVARES A ET AL. 2010. Antimicrobial photodynamic therapy: study of bacterial recovery viability and potential development of resistance after treatment. Mar Drugs 8: 91-105.

TAVARES A ET AL. 2011. Mechanisms of photodynamic inactivation of a Gram-negative recombinant bioluminescent bacterium by cationic porphyrins. Photochem Photobiol Sci 10: 1659-1669.

TEMIZEL E, SAGIR T, AYAN E, ISIK S AND OZTURK R. 2014. Delivery of lipophilic porphyrin by liposome vehicles: Preparation and photodynamic therapy activity against cancer cell lines. Photodiagnosis Photodyn Ther 11: 537-545.

TENG IT, CHANG YJ, WANG LS, LU HY, WU LC, YANG CM, CHIU CC, YANG CH, HSU SL AND HO JA. 2013. Phospholipid-functionalized mesoporous silica nanocarriers for selective photodynamic therapy of cancer. Biomaterials 34: 7462-7470.

THEODOSSIOU T, HOTHERSALL JS, WOODS EA, OKKENHAUG K, JACOBSON J AND MACROBERT AJ. 2003. Firefly luciferin-activated rose bengal: In vitro photodynamic therapy by intracellular chemiluminescence in transgenic NIH 3T3 cells. Cancer Res 63: 1818-1821.

TONG R AND CHENG J. 2007. Anticancer polymeric nanomedicines. Polym Rev 47: 345-381.

TORATANI S, TANI R, KANDA T, KOIZUMI K, YOSHIOKA Y AND OKAMOTO T. 2016. Photodynamic therapy using Photofrin and excimer dye laser treatment for superficial oral squamous cell carcinomas with long-term follow up. Photodiagnosis Photodyn Ther 14: 104-110.

TORCHILIN VP. 2001. Structure and design of polymeric surfactant-based drug delivery systems. J Control Release 73: $137-172$.

TORCHILIN VP. 2002. PEG-based micelles as carriers of contrast agents for different imaging modalities. Adv Drug Deliv Rev 54: 235-252.

TORCHILIN VP. 2007. Micellar nanocarriers: Pharmaceutical perspectives. Pharm Res 24: 1-16.

TOSTI A, PIRACCINI BM, VINCENZI C AND MISCIALI C. 2005. Permanent alopecia after busulfan chemotherapy. Br J Dermatol 152: 1056-1058.

TRIESSCHEIJN M, BAAS P, SCHELLENS JHM AND STEWART F. 2006. Photodynamic therapy in oncology. Oncologist 11: 1034-1044.

TSAI CP, HUNG Y, CHOU YH, HUANG DM, HSIAO JK, CHANG C, CHEN YC AND MOU CY. 2008. Highcontrast paramagnetic fluorescent mesoporous silica 
nanorods as a multifunctional cell-imaging probe. Small 4: 186-191.

VAN HILLEGERSBERG R, KORT WJ AND WILSON JHP. 1994. Current status of photodynamic therapy in oncology. Drugs 48: 510-527.

VAN NOSTRUM CF. 2004. Polymeric micelles to deliver photosensitizers for photodynamic therapy. Adv Drug Deliv Rev 56: 9-16.

VIEIRA L, CASTILHO ML, FERREIRA I, FERREIRASTRIXINO J, HEWITT KC AND RANIERO L. 2017. Synthesis and characterization of gold nanostructured Chorin e6 for Photodynamic Therapy. Photodiagnosis Photodyn Ther 18: 6-11.

VINOGRADOV S, BATRAKOVA E, LI S AND KABANOV A. 1999. Polyion complex micelles with protein-modified corona for receptor-mediated delivery of oligonucleotides into cells. Bioconjug Chem 10: 851-860.

WINCKLER KD. 2007. Special section: Focus on antimicrobial photodynamic therapy (PDT). J Photochem Photobiol B 86: 43-44.

WÖHRLE D, MULLER S, SHOPOVA M, MANTAREVA V, SPASSOVA G, VIETRI F, RICCHELLI F AND JORI G. 1999. Effect of delivery system on the pharmacokinetic and phototherapeutic properties of bis(methyloxyethyleneoxy) silicon-phthalocyanine in tumor-bearing mice. J Photochem Photobiol B 50: 124-128.

WU SH, LIN YS, HUNG Y, CHOU YH, HSU YH, CHANG C AND MOU CY. 2008. Multifunctional mesoporous silica nanoparticles for intracellular labeling and animal magnetic resonance imaging studies. ChemBioChem 9: 53-57.

XU F, DING L, TAO W, YANG XZ, QIAN HS AND YAO RS. 2016. Mesoporous-silica-coated upconversion nanoparticles loaded with vitamin B12 for near-infraredlight mediated photodynamic therapy. Mater Lett 167: 205-208
YASUGI K, NAKAMURA T, NAGASAKI Y, KATO M AND KATAOKA K. 1999. Sugar-installed polymer micelles: synthesis and micellization of poly(ethylene glycol)poly(D,L-lactide) block copolymers having sugar groups at the PEG chain end. Macromolecules 32: 8024-8032.

ZENG S, YONG KT, ROY I, DINH XQ, YU X AND LUAN F. 2011. A review on functionalized gold nanoparticles for biosensing applications. Plasmonics 6: 491-506.

ZHANG D, TAO L, ZHAO H, YUAN H AND LAN M. 2015. A functional drug delivery platform for targeting and imaging cancer cells based on Pluronic F127. J Biomater Sci Polym Ed 26: 468-482.

ZHANG W, SHEN J, SU H, MU G, SUN JH, TAN CP, LIANG XJ, JI LN AND MAO ZW. 2016. Co-delivery of cisplatin prodrug and chlorin e 6 by mesoporous silica nanoparticles for chemo-photodynamic combination therapy to combat drug resistance. ACS Appl Mater Interfaces 8: 1333213340.

ZHANG Z, SUN Q, ZHONG J, YANG Q, LI H, CHENG D, LIANG B AND SHUAI X. 2014. Magnetic resonance imaging-visible and $\mathrm{pH}$-sensitive polymeric micelles for tumor targeted drug delivery. J Biomed Nanotechnol 10: 216-226.

ZHAO L, KIM TH, AHN JC, KIM HW AND KIM SY. $2013 \mathrm{a}$. Highly efficient "theranostics" system based on surfacemodified gold nanocarriers for imaging and photodynamic therapy of cancer. J Mater Chem B 1: 5806-5817.

ZHAO L, KIM TH, HUH KM, KIM HW AND KIM SY. 2013 b. Self-assembled photosensitizer-conjugated nanoparticles for targeted photodynamic therapy. J Biomater Appl 28: 434-447.

ZHAO L, KIM TH, KIM HW, AHN JC AND KIM SY. 2016. Enhanced cellular uptake and phototoxicity of Verteporfinconjugated gold nanoparticles as theranostic nanocarriers for targeted photodynamic therapy and imaging of cancers. Mater Sci Eng C 67: 611-622. 